Grand Valley State University

ScholarWorks@GVSU

Spring 2011

\title{
Environmental Variation, Fish Community Composition, and Brown Trout Survival in the Pigeon River, Ottawa County, Michigan
}

Neil W. MacDonald

Grand Valley State University, macdonan@gvsu.edu

Daniel W. Mays

Little River Band of Ottawa Indians

Richard R. Rediske

Annis Water Resources Institute, redisker@gvsu.edu

Carl R. Ruetz III

Annis Water Resources Institute, ruetzc@gvsu.edu

Follow this and additional works at: https://scholarworks.gvsu.edu/biopeerpubs

\section{ScholarWorks Citation}

MacDonald, Neil W.; Mays, Daniel W.; Rediske, Richard R.; and Ruetz, Carl R. III, "Environmental Variation, Fish Community Composition, and Brown Trout Survival in the Pigeon River, Ottawa County, Michigan" (2011). Peer Reviewed Publications. 34.

https://scholarworks.gvsu.edu/biopeerpubs/34

This Article is brought to you for free and open access by the Biology Department at ScholarWorks@GVSU. It has been accepted for inclusion in Peer Reviewed Publications by an authorized administrator of ScholarWorks@GVSU. For more information, please contact scholarworks@gvsu.edu. 


\title{
Environmental Variation, Fish Community Composition, and Brown Trout Survival in the Pigeon River, Ottawa County, Michigan
}

\author{
NEIL W. MACDONALD \\ Grand Valley State University
}

DANIEL W. MAYS

Natural Resources Department, Little River Band of Ottawa Indians

RICHARD R. REDISKE AND CARL R. RUETZ III

Annis Water Resources Institute, Grand Valley State University

\begin{abstract}
The Pigeon River, a small coolwater stream in western Michigan, has a history of hydrologic, stream habitat, and water quality degradation that led to the loss of its trout population by the late 1980s. After regulatory and watershed management efforts to reduce point-and nonpoint source pollution in the 1990s, the Michigan Department of Natural Resources reinstituted brown trout (Salmo trutta) stocking in 2003. As part of these efforts, we monitored water quality in the Pigeon River each fall between 1996 and 2008, and conducted stream surveys in 2006 and 2007 to evaluate the fish community and outcome of trout stocking. Water quality tended to improve and stabilize through time, although point-and nonpoint source pollution still contributed to water quality problems. Hydrologic instability, caused by wetland drainage, agricultural land use, and irrigation withdrawals from the lower mainstream, created periods of environmental stress. As a result, the fish community of the Pigeon River was dominated by common tolerant warmwater species, typical of agricultural watersheds in southern Michigan. Nonetheless, brown trout surviving from initial stockings in 2003 and 2004 had attained lengths of between 18 and 24 inches by 2007, suggesting the thermal regime, water quality, stream habitat, and forage base of macroinvertebrates and small fish were suitable to maintain a stocked brown trout population. Continued efforts to improve water quality, protect instream habitat, reduce high stormflows, and maintain adequate summer baseflows are needed to fully restore environmental conditions for the native fish community and stocked brown trout in the Pigeon River.
\end{abstract}




\section{INTRODUCTION}

Fish communities in many Midwestern streams have been degraded as a result of a variety of anthropogenic factors including agricultural nonpoint source pollution, wetland drainage, stream channel modification, toxic waste discharge, water withdrawal, and exotic species introduction (Karr et al. 1985). Management efforts to improve fish communities in degraded streams often focus on physical or chemical aspects of water quality, even though improvement in these measures may take extended monitoring periods to detect because of the lag time between adoption of management practices and watershed response (Meals et al. 2010). In addition to in-stream water quality, fish community composition is strongly affected by watershed land use (Roth et al. 1996), stream habitat characteristics (Gorman and Karr 1978; Neumann and Wildman 2002), hydrologic stability (Bain et al. 1988; Poff and Allan 1995), and their interactive effects on stream temperature (Poole and Berman 2001). Chemical monitoring alone does not account for the effects of human-induced perturbations such as alterations in flow or physical habitat degradation (Karr et al. 1985), and biotic assessments of fish communities can provide a more integrated view of overall stream condition (Karr 1981; Eklov et al. 1998). Recent efforts to improve the Pigeon River, a small coolwater stream in western Michigan (Zorn et al. 2008; Lyons et al. 2009), provide a case study of both the consequences of past degradation and the ongoing challenges to restoration of water quality, hydrology, and a desirable fish community in a heavily human-perturbed system.

The Pigeon River is a small coastal stream that drains a 16,765 ha agricultural watershed in western Ottawa County, Michigan, and discharges into south-central Lake Michigan (Figure 1). This stream has a typical history of degradation related to the effects of agricultural nonpoint source pollution, extensive drainage of wetlands in the 1920s (Anonymous 1919), stream channelization, and point source discharges, all of which led to a documented decline in its biotic condition by the late 1980s (Creal and Wuycheck 1998). For example, the mainstream of the Pigeon River is designated as a coldwater fishery by the State of Michigan, but cessation of stocking in the late 1960s combined with degraded water quality in the 1980s resulted in the loss of its trout population (PRWAC 1997; Wiley and Seelbach 1998). In the mid-1990s, regulatory action by state agencies to bring a point source discharge into compliance occurred simultaneously with the initiation of cooperative efforts to reduce nonpoint source pollution through the Pigeon River Watershed Project (PRWAC 1997). The watershed project adopted specific goals to improve water quality and restore the coldwater fishery (PRWAC 1997). Wiley and Seelbach (1998), who completed an ecological assessment of the Pigeon River for the watershed project, concluded that while more extensive surveys of 


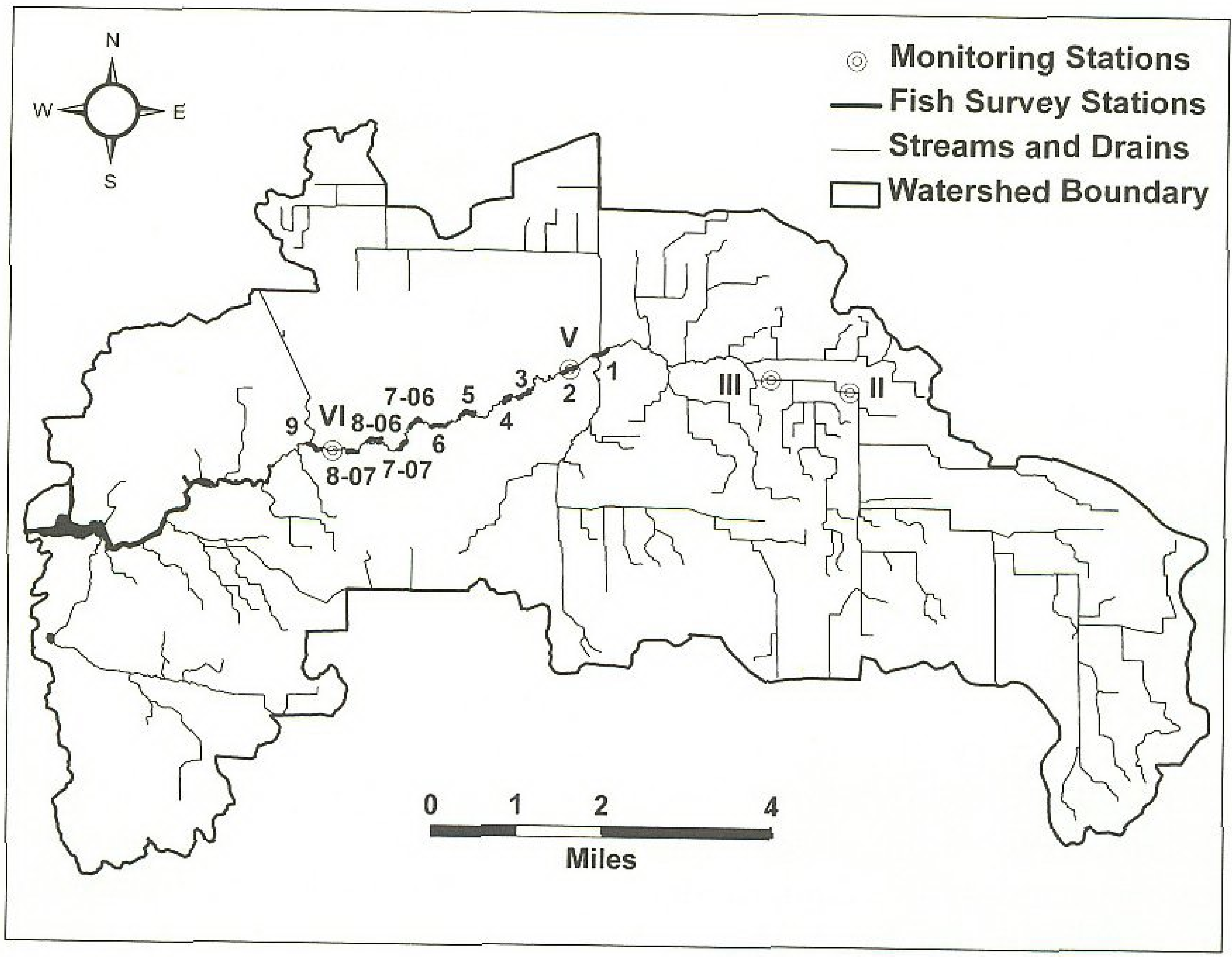

FIGURE 1. Pigeon River watershed in Ottawa County, Michigan, showing locations of water quality monitoring (II-VI) and fish survey (1-9) stations. Locations of fish survey stations 7 and 8 were moved from $2006(-06)$ to $2007(-07)$ to better represent the main channel of the river.

temperature, baseflows, and channel habitats were needed, thermal regimes in the lower mainstream supported the possibility of reestablishing a managed trout population. Based upon this assessment, Wiley and Seelbach (1998) recommended that experimental stocking of trout be undertaken, with follow-up studies to determine survivorship, growth, and dispersal through the lower mainstream.

As part of watershed project activities to document changes in water quality through time, a study of water chemistry and hydrology conducted between September 1996 and October 2000 (MacDonald et al. 2001) confirmed that both point- and nonpoint sources contributed to chronically impaired water quality in the upper reaches of the Pigeon River. Episodic inputs of degraded water during summer high flows also produced increased stream temperatures and decreased dissolved oxygen concentrations extending to the lower mainstream. It had been assumed that these inputs of degraded water from upstream would limit the fish population in the lower Pigeon River to a depauperate community of pollution-tolerant species (Wiley and Seelbach 1998; MacDonald et al. 2001), but no extensive fish 
surveys had been undertaken at that time. By the early 2000s, however, results of water quality monitoring studies documented improvements in water quality (MacDonald et al. 2001) and confirmed the coolwater thermal regime (Wehrly et al. 2003; Zorn et al. 2008; Lyons et al. 2009) of the lower mainstream of the Pigeon River. Based on the results of these studies, the Michigan Department of Natural Resources (MDNR) reinstituted brown trout stocking in the Pigeon River in 2003 (MDNR 2010). To assess the long-term effects of watershed-scale efforts to reduce point- and nonpoint source pollution, we have continued to monitor water quality in this stream each fall since 1996. In cooperation with the MDNR, in 2006 and 2007 we also conducted additional fish, habitat, and hydrologic surveys, as previously recommended by Wiley and Seelbach (1998). Our objectives were to examine trends in water quality through time, to quantify existing stream habitat, to determine the composition of the fish community, and to evaluate the outcome of brown trout stocking. All of these studies were conducted in specific support of ongoing community efforts to improve the Pigeon River for its designated uses. The results of these studies provide a detailed view of the possibilities for and constraints on watershed-scale improvements in a coolwater system that has been extensively degraded by human activities.

\section{METHODS}

\section{Water Quality Monitoring Stations}

Since 1996, we monitored water quality each fall at four locations on the mainstream of the Pigeon River, as previously identified by MacDonald et al. (2001). Stations II and III are located on the Blendon and Olive drain that forms the headwaters of the Pigeon River (Figure 1). Station III also is downstream from a major point source discharge of meat-packing/foodprocessing wastewater within the watershed. Station $V$ is near the upper end of the state-designated coldwater management section of the stream, and Station VI is near the lower end of this section above Lake Michigan. While the entire stream is a designated county drain to below Station VI, downstream of Station III the mainstream enters a well-defined valley with an intact forested floodplain and natural stream channel characteristics (Wiley and Seelbach 1998).

\section{Water Quality Sampling}

We collected data and samples at the four monitoring stations once each month in September, October, and November from 1996 to 2008. The fall represents a period of relatively stable hydrology in the Pigeon River (MacDonald et al. 2001), but also incorporates normal seasonal increases in 
baseflow from late summer to late fall. On all sampling dates and at each station, we measured water temperatures using a hand-held meter (YSI Model 55, YSI, Inc., Yellow Springs, OH), and collected duplicate $125 \mathrm{~mL}$ samples for $\mathrm{pH}$ and conductivity analyses. We collected and chemically fixed one $300 \mathrm{~mL}$ sample at each station to measure dissolved oxygen levels using the Winkler titration method. We determined discharge by measuring stream velocities at $60 \%$ depth at intervals across the stream using a Teledyne Gurley Model 625 Pygmy water current meter (Teledyne Gurley, Troy, NY).

We performed conductivity, $\mathrm{pH}$, and dissolved oxygen analyses immediately upon return from the field. We measured conductivity with a YSI Model 35 conductance meter (YSI, Inc., Yellow Springs, OH), determined pH with a Cole-Parmer Series $5986 \mathrm{pH}$ meter (Cole-Parmer Instrument Co., Vernon Hills, IL), and completed dissolved oxygen titrations with a Hach digital titrator (Hach Co., Loveland, CO). Mean values for $\mathrm{pH}$ and conductivity were calculated from the replicate samples, and dissolved oxygen concentrations were based on a minimum of two determinations from each $300 \mathrm{~mL}$ sample. Repeated-measurement errors for these analyses were $1.0 \%$ for conductivity, $0.6 \%$ for $\mathrm{pH}$, and $1.1 \%$ for dissolved oxygen, similar to what we reported for an earlier study (MacDonald et al. 2001). We also collected a $1 \mathrm{~L}$ water sample at each station to measure $\mathrm{Cl}, \mathrm{SO}_{4}, \mathrm{NH}_{4}-\mathrm{N}, \mathrm{NO}_{3}-\mathrm{N}, \mathrm{PO}_{4}-\mathrm{P}$, and total suspended solids concentrations. We followed standard protocols (APHA 1992) for these analyses: $\mathrm{Cl}, \mathrm{SO}_{4}, \mathrm{NO}_{3}-\mathrm{N}$ (4110-ion chromatography), $\mathrm{NH}_{4}-\mathrm{N}$ (4500$\mathrm{NH} 3[\mathrm{G}]$-automated phenate), $\mathrm{PO}_{4}-\mathrm{P}$ (soluble reactive phosphate, 4500$\mathrm{P}[\mathrm{E}]$-automated ascorbic acid), and suspended solids (2540[D]-gravimetric). The laboratory quality assurance protocol for these analyses included one matrix spike and matrix-spiked duplicate for each sampling date in addition to daily analysis of blanks and calibration standards. All samples were analyzed at the Annis Water Resources Institute laboratory using quality assurance acceptance criteria of $\pm 20 \%$ for precision and accuracy of project samples and $\pm 10 \%$ for calibration standards.

\section{Fish Survey Study Sites}

In spring 2006 we established nine $1000 \mathrm{ft}$ survey stations in the designated coldwater management stretch of the Pigeon River in Olive and Port Sheldon Townships of Ottawa County. Three stations (1-3) were surveyed in the upper portion, three stations (4-6) were surveyed in the middle portion, and three stations (7-9) were surveyed in the lower portion of this stretch (Figure 1). Between Stations 6 and 9, the stream splits into several channels, and in 2007 we moved the locations for fish survey Stations 7 and 8 to better represent the main flow of the river in this area. 
Since we followed a standard protocol developed by the MDNR for the fish surveys and related habitat measurements that uses English units (Wills et al. 2006), all results related to these surveys are reported in those units.

As part of the fish surveys, once each month from May to August 2006 we determined dissolved oxygen levels, performed chemical analyses, and measured stream flows at fish survey Stations 3, 5, 8, and 9 as previously described. We also placed continuous water temperature recorders (Hobo Water Temp Pro V2, Onset, Bourne, MA) at these four stations to record stream temperatures at 1 -hour intervals throughout the 2006 study period. To provide detailed records of both temperature and discharge from June to October in 2007 above and below a major irrigation withdrawal downstream from Station 6, we installed water-level loggers (Hobo U20, Onset, Bourne, MA) in the mainstream at Stations 3 and 7 (7-07, Figure 1) to record water depths and temperatures at 10-minute intervals. We used the continuous temperature data collected in 2006 and 2007 to classify the stream's thermal regime as detailed in Lyons et al. (2009). We estimated stream discharge from the 2007 water level data using rating curves developed from measured discharges and stormflow discharges predicted using a HEC-HMS watershed model developed by the Michigan Department of Environmental Quality (MDEQ).

\section{In-Stream Habitat Conditions}

In mid-July 2006 we systematically sampled at $75 \mathrm{ft}$ intervals (Wills et al. 2006) throughout each $1000 \mathrm{ft}$ fish survey station to characterize stream physical characteristics. At each interval, we measured stream width and depths, characterized riparian vegetation, determined bottom substrate at four locations across the stream, and classified the specific habitat type (pool, riffle, or run). We also measured the basal area of the surrounding forest at each point with a 10-factor basal area prism and estimated the canopy density of streamside vegetation using a spherical densitometer (Forest Densitometers, Bartlesville, AR). We quantified large woody debris ( $>6$ in diameter) for entire $1000 \mathrm{ft}$ stretches. Qualitative and quantitative measurements of the relative proportions of substrate, woody debris, and habitat types were conducted and recorded as detailed in Wills et al. (2006).

\section{Fish Community Assessment}

All fish survey data were collected following standard MDNR procedures (Wills et al. 2006). Fish populations were surveyed at each station in late June, late July to early August, and October to November in 2006, and in mid-July 2007. During all sampling periods, we used one-pass electrofishing to qualitatively characterize the composition of the fish population. Fish sampling was performed with an AbP-3 pulsed-DC backpack electroshocker 
and at least two netters. All fish were identified to species and their total lengths were measured to the nearest $0.25 \mathrm{in}$. To determine the age-class distribution of brown trout, scale samples were taken from each brown trout collected during the August 2006 sampling period (Mays 2007).

\section{Statistical Analyses}

Water quality data (1996-2008) were analyzed using a repeated-measures analysis of variance (ANOVA) with monitoring stations considered a fixed effect, months treated as a block effect, and the year effect incorporated as the repeated measure. ANOVAs for July 2006 water quality variables were conducted with survey stations considered a fixed effect and by treating sampling dates as a block effect. Standard deviations in daily stream temperatures and flows measured between mid-June and mid-September in 2007 at fish survey Stations 3 and 7 were calculated from mean hourly values $(\mathrm{n}=24$ per day). Mean standard deviations were compared between these two stations using a one-way ANOVA treating stations as a fixed effect and days as replicates. Data were statistically analyzed using least-squares ANOVA (SYSTAT, Version 4, Wilkinson 1989), and we used Tukey's multiple comparison test to judge significant differences among sample means for all analyses (Steel and Torrie 1980). We used nonmetric multidimensional scaling (McCune and Grace 2002) to examine variation in fish community composition among fish survey stations and sampling dates using PC-ORD (Version 5, McCune and Mefford 2006). For this analysis, fish community composition at each station and sampling date was expressed as a percent of the total catch in 11 common species groups (brown trout, darter spp., pike and pickerel spp., largemouth bass, central mudminnow, pirate perch, round goby, shiner spp., sunfish spp., white sucker, and other spp.).

\section{RESULTS}

\section{Water Quality and Hydrology}

Mean fall discharge varied significantly among years between 1996 and 2008 (Table 1), and was correlated with previous six-month precipitation (July through November, $\mathrm{r}=0.88, \mathrm{P}<0.001$ ) recorded in Muskegon, Michigan (NCDC 2009). Annual variations in flow affect certain aspects of water quality, especially during years of low or high flows (Table 1). The point source discharge in the upper watershed exerts substantial influence on water chemistry during periods of low flows, as evidenced by the higher conductivity and solute concentrations observed in 1999, 2002, and 2005 (Table 1). In contrast, conductivity and solute concentrations tended to be much lower during years of high flows as a result of dilution (e.g., 2000, 2008, Table 1). 


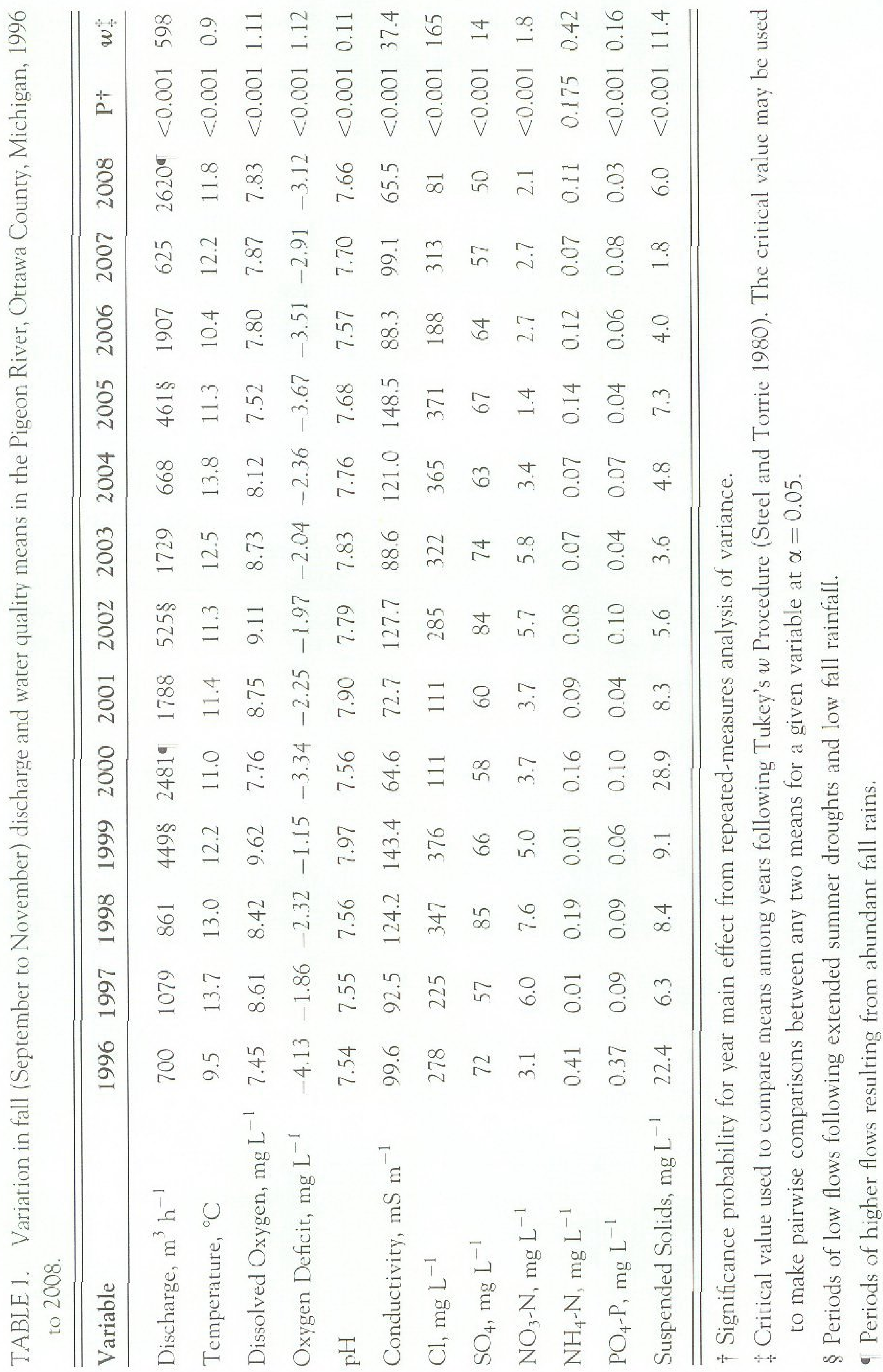


Overall water quality, especially in terms of oxygen deficits, $\mathrm{NH}_{4}-\mathrm{N}$ concentrations, and $\mathrm{PO}_{4}-\mathrm{P}$ concentrations, was severely degraded in 1996 as a result of the chronic discharge of poorly treated effluent from the point source in the upper watershed. After the MDEQ took regulatory action in 1997 the resulting upgrades to wastewater treatment facilities, combined with the elimination of on-site poultry slaughtering, produced noticeable improvements in water quality during the next several years. Since the highest concentrations observed in the late $1990 \mathrm{~s}, \mathrm{SO}_{4}, \mathrm{NO}_{3}-\mathrm{N}, \mathrm{PO}_{4}-\mathrm{P}$, and suspended solids concentrations in the Pigeon River declined significantly and stabilized at relatively low levels after 2000 , even during periods of low and high flows (Table 1). A similar trend in $\mathrm{NH}_{4}-\mathrm{N}$ concentrations was apparent, but concentrations of this nutrient were highly variable and this effect was not significant (Table 1). Although mean dissolved oxygen concentrations have tended to be lower in recent years, the highest values observed prior to 2003 were associated with periods of low flows and algal blooms that produced supersaturated conditions in the unshaded channel at monitoring Stations II and III (Figure 1; Table 1). Since 2003, water quality in the Pigeon River has continued to show signs of gradual improvement, especially for $\mathrm{NO}_{3}-\mathrm{N}, \mathrm{PO}_{4}-\mathrm{P}$, and suspended solids concentrations (Table 1).

Water quality in the Pigeon River during the summer of 2006 (Table 2) was consistent with that observed during annual fall monitoring. Summer inorganic ion concentrations measured in the lower mainstream of the Pigeon River (Table 2) were similar to those observed since 2003 during fall (Table 1). $\mathrm{SO}_{4}$ concentrations decreased from fish survey Station 3 to Station 9 (Table 2), likely a result of dilution by groundwater in the lower Pigeon River (MacDonald et al. 2001). Conductivity and other solute concentrations also tended to decrease downstream, although not significantly (Table 2). Mean dissolved oxygen concentrations increased while oxygen deficits decreased from fish survey Station 3 to Station 9 as water quality improved downstream, consistent with trends previously observed in this system (MacDonald et al. 2001).

In 2006, mean and maximum summer stream temperatures in the mainstream of the Pigeon River placed it in the coolwater thermal habitat classification proposed by Lyons et al. (2009) for Michigan streams (Table 3). Based upon mean July temperatures between 17.5 and 19.5 degrees $C$, the Pigeon River falls into the coolwater/cold transition thermal regime, although maximum daily mean summer temperatures occasionally exceed the 22.6 degrees $\mathrm{C}$ upper limit for this category (Lyons et al. 2009). In 2007, the mean mid-June to mid-September standard deviation in daily stream temperature was higher below the irrigation withdrawal than above ( \pm $0.92^{\circ} \mathrm{C}$ vs. $\pm 0.81^{\circ} \mathrm{C} ; \mathrm{P}=0.04$ ). While these observations suggest that the irrigation withdrawal impacted the magnitude of daily temperature 


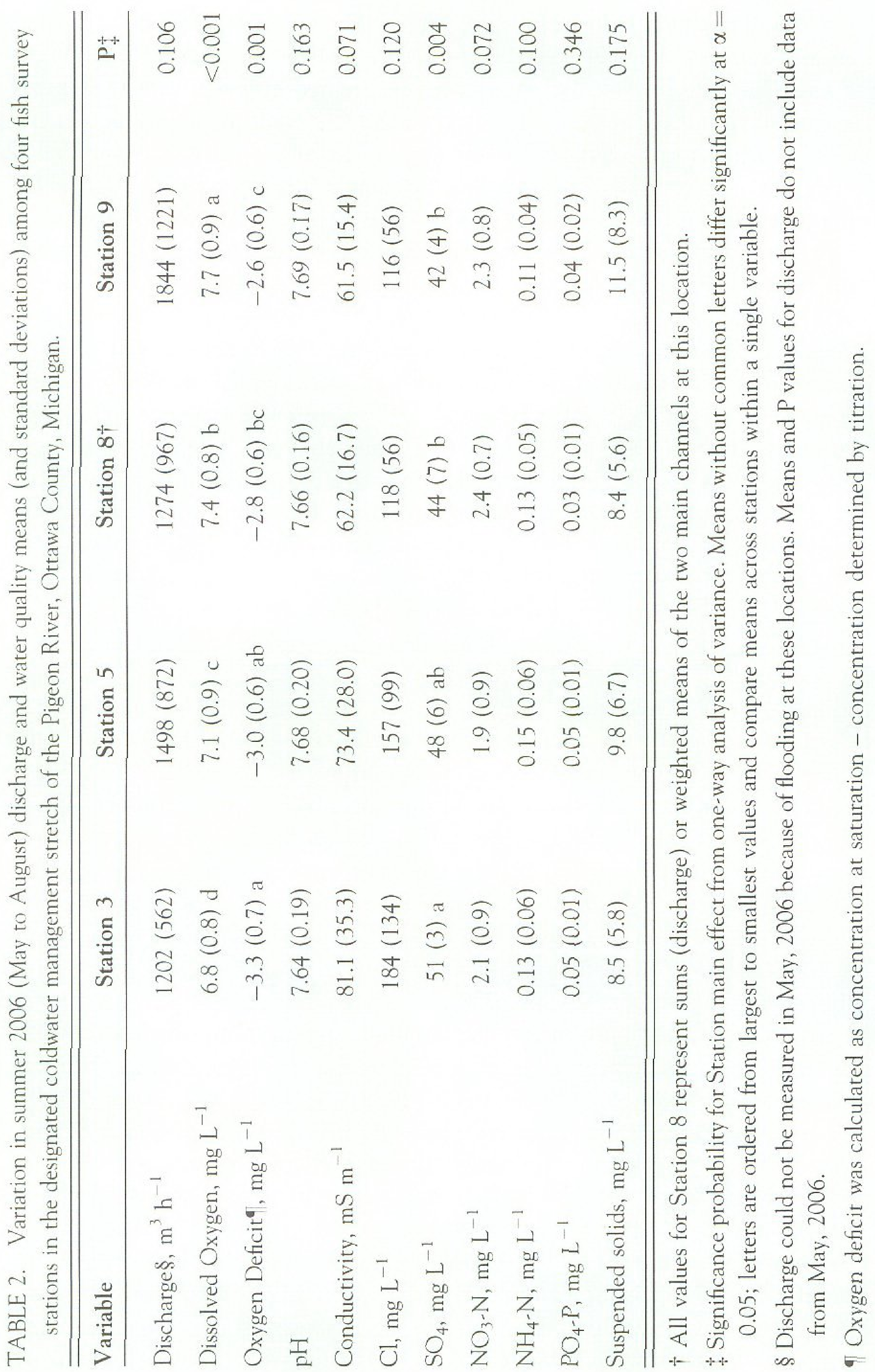


TABLE 3. Thermal classification of fish survey stations on the Pigeon River, Ottawa County, Michigan, based upon measured water temperatures in 2006 and 2007.

Thermal classes assigned following water temperature criteria developed by Lyons et al. (2009).

\begin{tabular}{cccccl}
\hline \hline Year & $\begin{array}{c}\text { Survey } \\
\text { Station }\end{array}$ & $\begin{array}{c}\text { June-August } \\
\text { Mean }{ }^{\circ} \mathrm{C}\end{array}$ & $\begin{array}{c}\text { July } \\
\text { Mean }{ }^{\circ} \mathrm{C}\end{array}$ & $\begin{array}{c}\text { Maximum } \\
\text { Daily } \\
\text { Mean }{ }^{\circ} \mathrm{C}\end{array}$ & $\begin{array}{c}\text { Thermal Class } \\
\text { and Subclass }\end{array}$ \\
\hline 2006 & 3 & 17.6 & 18.9 & 23.2 & $\begin{array}{c}\text { Coolwater - cold to warm } \\
\text { transition }\end{array}$ \\
2006 & 5 & 17.1 & 18.3 & 22.5 & Coolwater - cold transition \\
2006 & 8 & 16.8 & 17.9 & 21.6 & Coolwater - cold transition \\
2006 & 9 & 17.0 & 17.9 & 21.9 & Coolwater - cold transition \\
2007 & 3 & 16.9 & 16.2 & 20.2 & Coldwater \\
\hline \hline
\end{tabular}

variation, stream temperatures measured at both stations during summer 2007 fell into the coldwater thermal regime (Table 3).

Average summer flows measured in 2006 (Table 2) were similar to the average summer baseflow of $1600 \mathrm{~m}^{3} \mathrm{~h}^{-1}$ determined at West Olive Road (monitoring Station VI, Figure 1) between 1997 and 2000 (MacDonald et al. 2001), but the reduction in flow between fish survey Stations 5 and 8 appeared to be the result of irrigation withdrawals below Station 6. The continuous stream hydrographs measured during summer 2007 confirmed several aspects of hydrology in this stream (Figure 2). First, its flashy response to rainfall is reflected by the rapid increases in flow after periods of rain in late August (12.5 cm from August 19-25; NCDC 2007) and October (5.3 cm from October 18-23; NCDC 2007), with stream discharge rising quickly as the extensive system of county drains delivered stormwater to the mainstream of the Pigeon River below monitoring Station III. Second, low mid-summer baseflows $\left(<600 \mathrm{~m}^{3} \mathrm{~h}^{-1}\right)$ were clearly evident at both locations in 2007 (Figure 2). Finally, while small variations in flow occurred as a result of the daily evapotranspiration cycle, as seen at Station 3 (Figure 2a), the pronounced impact of daytime irrigation withdrawal on discharge at Station 7 (Figure 2b) was readily apparent, with almost half of the total flow of the stream being diverted during periods of low flow and heavy irrigation withdrawal. Mean mid-June to mid-September standard deviations in daily flow below the irrigation 

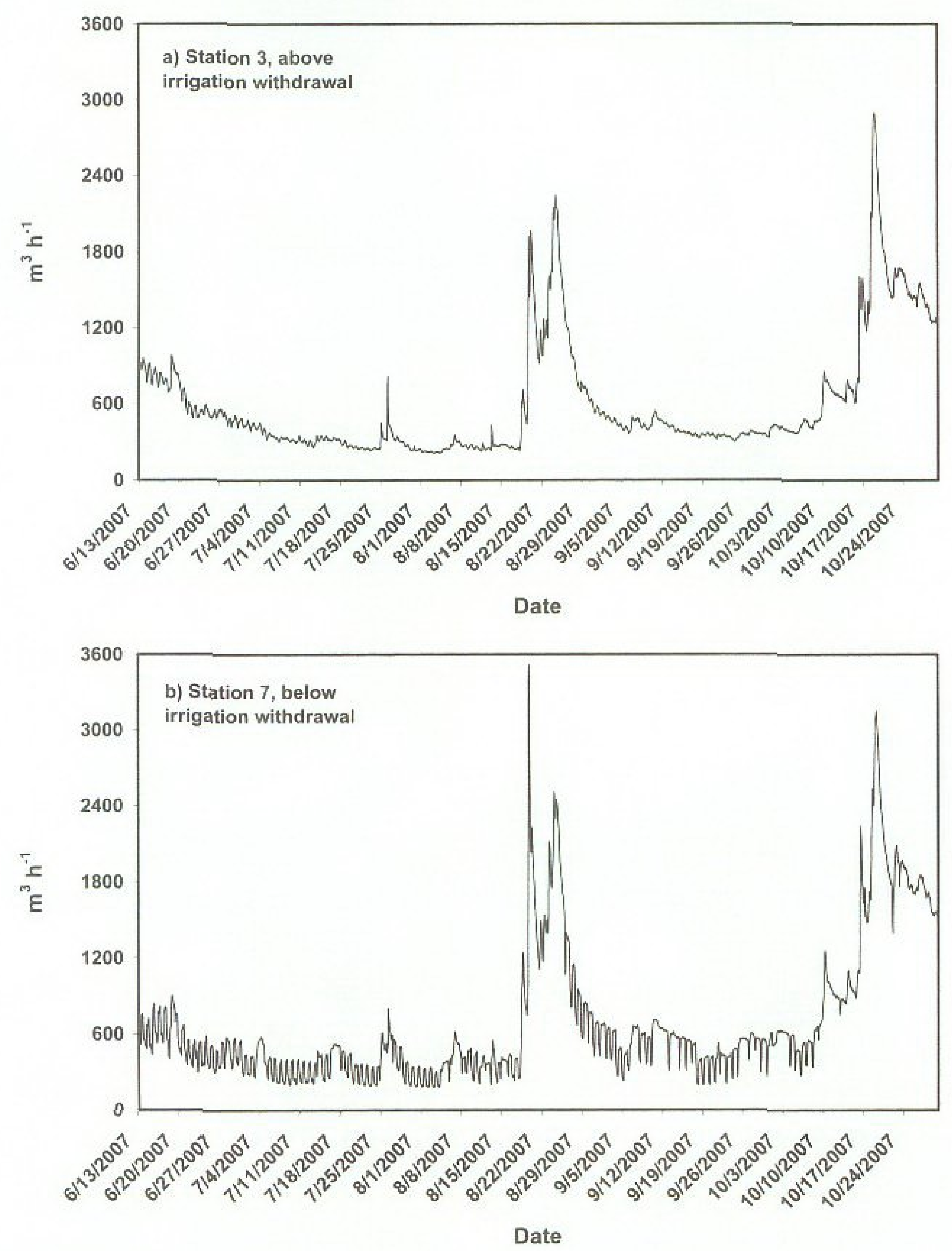

FIGURE 2. Variation in mean hourly discharge during the summer of 2007 at Stations 3 and 7 (Sections 9 and 7, T6N R15W, Ottawa County, Michigan) on the Pigeon River a) above and b) below a large irrigation withdrawal.

withdrawal in 2007 were significantly greater than those observed above the irrigation withdrawal $\left( \pm 104 \mathrm{~m}^{3} \mathrm{~h}^{-1}\right.$ vs. $\left.\pm 43 \mathrm{~m}^{3} \mathrm{~h}^{-1} ; \mathrm{P}<0.001\right)$.

\section{Stream and Habitat Characteristics}

Stream widths and depths were fairly similar at all nine fish survey stations, although average widths were greatest at Stations 1 and 6 while average depths were greatest at Stations 4 and 9 (Table 4). Stations 7 and 8 , as sampled in 2006, had the smallest channel dimensions because they were both side channels in the river where it splits into several channels downstream of Station 6. All stations were well-shaded by riparian vegetation and did not differ in canopy cover (Table 4). All stations had riparian forest basal areas in excess of $80 \mathrm{ft}^{2} \mathrm{ac}^{-1}$ (Table 4), typical of fully- 
TABLE 4. Average (and standard deviation) stream channel and riparian vegetation characteristics in nine $1000 \mathrm{ft}$ stretches of the Pigeon River, Ottawa County, Michigan, in July 2006.

\begin{tabular}{lccccc}
\hline \hline Station & $\begin{array}{c}\text { Width } \\
\text { feet }\end{array}$ & $\begin{array}{c}\text { Depth } \begin{array}{c}\text { Thalweg } \\
\text { feet }\end{array} \\
\text { feet }\end{array}$ & $\begin{array}{c}\text { Canopy§ } \\
\%\end{array}$ & $\begin{array}{c}\text { Basal Area } \\
\mathrm{ft}^{2} \mathrm{ac}^{-1}\end{array}$ \\
\hline 2 & $26.2(7.2)$ & $0.93(0.43)$ & $1.49(0.76)$ & $84.9(8.9)$ & $86(37)$ \\
3 & $20.8(4.2)$ & $1.15(0.52)$ & $1.83(0.76)$ & $82.9(11.5)$ & $102(40)$ \\
4 & $22.6(4.6)$ & $0.77(0.19)$ & $1.17(0.34)$ & $89.3(12.2)$ & $130(44)$ \\
5 & $22.5(6.1)$ & $1.51(0.69)$ & $2.20(0.87)$ & $83.5(13.2)$ & $98(34)$ \\
6 & $22.5(3.5)$ & $1.09(0.28)$ & $1.67(0.43)$ & $87.4(9.7)$ & $87(37)$ \\
7 & $23.7(5.0)$ & $1.26(0.59)$ & $1.92(0.82)$ & $76.0(19.6)$ & $81(39)$ \\
8 & $14.8(3.3)$ & $0.59(0.30)$ & $0.92(0.40)$ & $84.1(14.0)$ & $92(39)$ \\
9 & $17.1(3.7)$ & $0.56(0.25)$ & $0.86(0.41)$ & $80.1(17.3)$ & $96(32)$ \\
\hline \hline
\end{tabular}

$\dagger$ Average stream depth based on systematic measurements at $0.2,0.4,0.6$, and 0.8 times stream width at each transect.

* Average of the greatest stream depth found at each transect, typically where the greatest flow of water occurs.

$\S$ Average amount of overhead vegetative canopy cover along the stream stretch, measured from the center of the stream at each transect.

I Average basal area of surrounding forest as measured from the center of the stream at each transect using a basal area prism.

stocked forests, with the exception of Station 9, where tag alder became more common (Mays 2007). Most stretches contained substantial quantities of large woody debris (Figure $3 \mathrm{a}$ ) and areas of $\log$ jams and brush deposits (Figure 3b). The dominant bottom substrate throughout the Pigeon River was sand (Mays 2007), with only small amounts of material coarser than pea gravel found in any stretch. A few stations $(1,6,9)$ had localized areas of rubble, cobble, or gravel riprap added to control bank erosion that also provided fish habitat, but these areas were restricted in size and location (Figure 3b).

\section{Fish Community Composition}

We identified a total of 26 fish species in the Pigeon River during our surveys in 2006 and 2007 (Table 5). Abundant species ( $>15 \%$ of total 

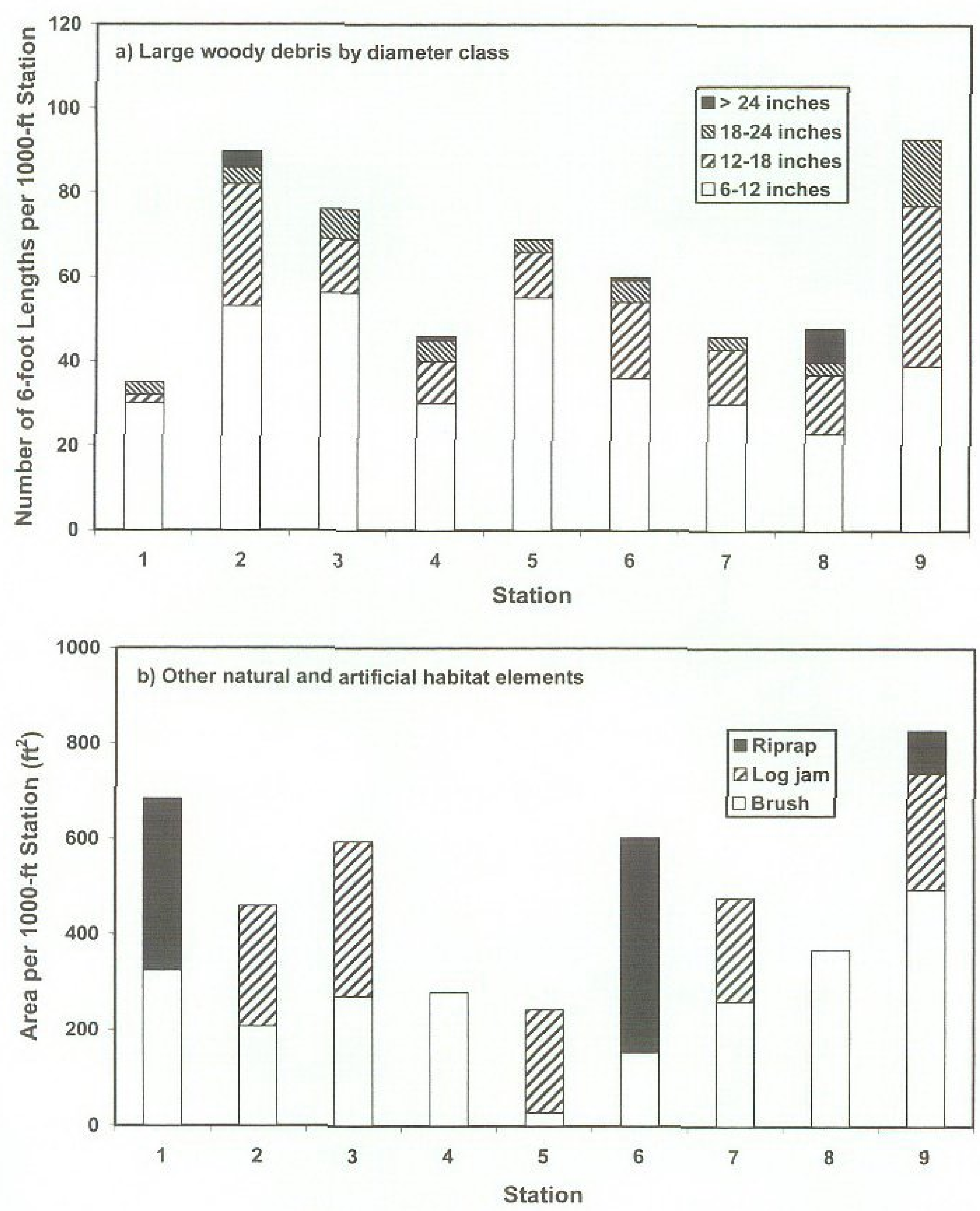

FIGURE 3. Structural habitat in the Pigeon River, Ottawa County, Michigan, including a) large woody debris by diameter class, and b) other natural and artificial habitat elements (2006).

catch) included central mudminnow (Umbra limi), johnny darter (Etheostoma nigrum), and green sunfish (Lepomis cyanellus, 60\% of all sunfish captured). Common species (5 to $10 \%$ of total catch) included blackside darter (Percina maculata), largemouth bass (Micropterus salmoides), bluegill (Lepomis macrochirus), pumpkinseed (Lepomis gibbosus), and round goby (Neogobius melanostomus). Smaller numbers (1 to $5 \%$ of total catch) of white sucker (Catostomus commersoni), grass pickerel (Esox americanus vermiculatus), brown trout, and pirate perch (Aphredoderus sayanus) also were found at most stations. All other species were uncommon to rare $(<1 \%$ of total catch), including common carp (Cyprinus carpio), rock bass (Ambloplites rupestris), northern pike (Esox lucius), logperch (Percina caprodes), and smallmouth bass (Micropterus dolomieui). 
TABLE 5. Number of fish captured per $1000 \mathrm{ft}$ survey station by species and sampling period in the Pigeon River, Ottawa County, Michigan. Sampling periods included June 20 to June 27, 2006; July 31 to August 7, 2006; October 14 to November 9, 2006; and July 16 to July $19,2007$.

\begin{tabular}{|c|c|c|c|c|c|c|c|c|c|c|c|}
\hline \multirow[b]{2}{*}{ Common Name } & \multirow[b]{2}{*}{ Sampling Period } & \multicolumn{9}{|c|}{ Survey Station } & \multirow{2}{*}{$\begin{array}{l}\text { Species } \\
\text { Totals }\end{array}$} \\
\hline & & 1 & 2 & 3 & 4 & 5 & 6 & 7 & 8 & 9 & \\
\hline \multirow[t]{4}{*}{ Blackside darter } & Jun, 2006 & 0 & 3 & 4 & 1 & 4 & 6 & 6 & 4 & 7 & 35 \\
\hline & Jul-Aug, 2006 & 0 & 0 & 4 & 4 & 6 & 7 & 0 & 8 & 25 & 54 \\
\hline & Oct-Nov, 2006 & 0 & 2 & 3 & 3 & 8 & 1 & 0 & 0 & 6 & 23 \\
\hline & Jul, 2007 & 0 & 3 & 1 & 1 & 0 & 6 & 3 & 12 & 19 & 45 \\
\hline \multirow[t]{4}{*}{ Brown trout } & Jun, 2006 & 1 & 3 & 0 & 1 & 1 & 3 & 4 & 0 & 1 & 14 \\
\hline & Jul-Aug, 2006 & 1 & 1 & 0 & 0 & 2 & 0 & 2 & 0 & 1 & 7 \\
\hline & Oct-Nov, 2006 & 0 & 2 & 0 & 0 & 0 & 2 & 0 & 0 & 2 & 6 \\
\hline & Jul, 2007 & 1 & 5 & 2 & 1 & 1 & 1 & 2 & 2 & 2 & 17 \\
\hline \multirow[t]{4}{*}{ Central mudminnow } & Jun, 2006 & 13 & 7 & 9 & 6 & 7 & 10 & 9 & 1 & 0 & 62 \\
\hline & Jul-Aug, 2006 & 23 & 19 & 28 & 8 & 17 & 14 & 23 & 15 & 3 & 150 \\
\hline & Oct-Nov, 2006 & 15 & 2 & 24 & 11 & 7 & 19 & 6 & 4 & 4 & 92 \\
\hline & Jul, 2007 & 39 & 36 & 24 & 16 & 13 & 26 & 6 & 4 & 7 & 171 \\
\hline \multirow[t]{2}{*}{ Common carp } & Jun, 2006 & 9 & 0 & 0 & 0 & 0 & 0 & 0 & 0 & 0 & 9 \\
\hline & Jul, 2007 & 5 & 0 & 0 & 0 & 0 & 0 & 0 & 0 & 0 & 5 \\
\hline \multirow[t]{4}{*}{ Grass pickerel } & Jun, 2006 & 1 & 3 & 1 & 0 & 0 & 0 & 2 & 0 & 1 & 8 \\
\hline & Jul-Aug, 2006 & 6 & 5 & 2 & 1 & 3 & 1 & 7 & 4 & 0 & 29 \\
\hline & Oct-Nov, 2006 & 1 & 3 & 4 & 3 & 2 & 0 & 0 & 1 & 1 & 15 \\
\hline & Jul, 2007 & 6 & 5 & 0 & 4 & 3 & 5 & 3 & 2 & 2 & 30 \\
\hline \multirow[t]{4}{*}{ Johnny darter } & Jun, 2006 & 19 & 9 & 15 & 12 & 2 & 4 & 6 & 4 & 7 & 78 \\
\hline & Jul-Aug, 2006 & 8 & 6 & 24 & 5 & 2 & 9 & 16 & 16 & 27 & 113 \\
\hline & Oct-Nov, 2006 & 8 & 4 & 21 & 5 & 11 & 12 & 2 & 3 & 2 & 68 \\
\hline & Jul, 2007 & 20 & 16 & 38 & 11 & 9 & 5 & 7 & 14 & 6 & 126 \\
\hline \multirow[t]{4}{*}{ Largemouth bass } & Jun, 2006 & 4 & 1 & 0 & 3 & 9 & 3 & 7 & 13 & 3 & 43 \\
\hline & Jul-Aug, 2006 & 5 & 2 & 4 & 4 & 5 & 5 & 0 & 11 & 2 & 38 \\
\hline & Oct-Nov, 2006 & 3 & 1 & 6 & 1 & 2 & 10 & 1 & 5 & 4 & 33 \\
\hline & Jul, 2007 & 1 & 0 & 0 & 0 & 1 & 0 & 1 & 0 & 0 & 3 \\
\hline
\end{tabular}


TABLE 5. (Continued)

\begin{tabular}{|c|c|c|c|c|c|c|c|c|c|c|c|}
\hline \multirow[b]{2}{*}{ Common Name } & \multirow[b]{2}{*}{ Sampling Period } & \multicolumn{9}{|c|}{ Survey Station } & \multirow{2}{*}{$\begin{array}{l}\text { Species } \\
\text { Totals }\end{array}$} \\
\hline & & 1 & 2 & 3 & 4 & 5 & 6 & 7 & 8 & 9 & \\
\hline \multirow[t]{3}{*}{ Logperch } & Jun, 2006 & 0 & 0 & 0 & 0 & 0 & 1 & 0 & 0 & 1 & 2 \\
\hline & Jul-Aug, 2006 & 0 & 0 & 0 & 0 & 2 & 0 & 0 & 0 & 4 & 6 \\
\hline & Jul, 2007 & 0 & 0 & 0 & 0 & 0 & 0 & 0 & 0 & 1 & 1 \\
\hline \multirow[t]{2}{*}{ Northern pike } & Jun, 2006 & 2 & 0 & 0 & 0 & 1 & 0 & 1 & 0 & 0 & 4 \\
\hline & Jul, 2007 & 2 & 1 & 0 & 0 & 0 & 1 & 1 & 0 & 1 & 6 \\
\hline \multirow[t]{4}{*}{ Pirate perch } & Jun, 2006 & 0 & 0 & 3 & 0 & 0 & 3 & 0 & 1 & 0 & 7 \\
\hline & Jul-Aug, 2006 & 0 & 2 & 0 & 2 & 1 & 3 & 0 & 0 & 0 & 8 \\
\hline & Oct-Nov, 2006 & 0 & 0 & 1 & 1 & 0 & 5 & 0 & 0 & 1 & 8 \\
\hline & Jul, 2007 & 0 & 1 & 0 & 0 & 0 & 0 & 0 & 0 & 1 & 2 \\
\hline Rainbow trout & Oct-Nov, 2006 & 1 & 0 & 0 & 0 & 0 & 1 & 0 & 0 & 0 & 2 \\
\hline \multirow[t]{4}{*}{ Rock bass } & Jun, 2006 & 0 & 0 & 1 & 0 & 0 & 2 & 0 & 0 & 1 & 4 \\
\hline & Jul-Aug, 2006 & 0 & 0 & 0 & 0 & 1 & 0 & 0 & 0 & 1 & 2 \\
\hline & Oct-Nov, 2006 & 0 & 0 & 0 & 0 & 2 & 0 & 0 & 1 & 0 & 3 \\
\hline & Jul, 2007 & 0 & 0 & 0 & 1 & 0 & 1 & 0 & 0 & 0 & 2 \\
\hline \multirow[t]{4}{*}{ Round goby } & Jun, 2006 & 0 & 3 & 4 & 4 & 6 & 7 & 0 & 2 & 26 & 52 \\
\hline & Jul-Aug, 2006 & 0 & 0 & 3 & 2 & 7 & 5 & 0 & 4 & 16 & 37 \\
\hline & Oct-Nov, 2006 & 0 & 0 & 0 & 0 & 1 & 0 & 0 & 0 & 2 & 3 \\
\hline & Jul, 2007 & 3 & 3 & 4 & 3 & 3 & 5 & 4 & 27 & 32 & 84 \\
\hline \multirow[t]{3}{*}{ Shiner spp. ${ }^{\dagger}$} & Jun, 2006 & 0 & 1 & 0 & 0 & 0 & 0 & 0 & 0 & 0 & 1 \\
\hline & Jul-Aug, 2006 & 0 & 0 & 1 & 0 & 0 & 0 & 0 & 0 & 1 & 2 \\
\hline & Oct-Nov, 2006 & 2 & 0 & 4 & 0 & 0 & 1 & 0 & 1 & 1 & 9 \\
\hline Smallmouth Bass & Jul-Aug, 2006 & 0 & 0 & 2 & 0 & 0 & 0 & 0 & 0 & 0 & 2 \\
\hline \multirow[t]{4}{*}{ Sunfish spp. } & Jun, 2006 & 23 & 20 & 16 & 15 & 18 & 17 & 28 & 23 & 18 & 178 \\
\hline & Jul-Aug, 2006 & 31 & 18 & 23 & 21 & 40 & 14 & 6 & 11 & 5 & 169 \\
\hline & Oct-Nov, 2006 & 6 & 5 & 15 & 17 & 23 & 42 & 4 & 16 & 10 & 138 \\
\hline & Jul, 2007 & 24 & 39 & 8 & 15 & 5 & 22 & 14 & 17 & 2 & 146 \\
\hline
\end{tabular}




\begin{tabular}{|c|c|c|c|c|c|c|c|c|c|c|c|}
\hline \multirow[b]{2}{*}{ Common Name } & \multirow[b]{2}{*}{ Sampling Period } & \multicolumn{9}{|c|}{ Survey Station } & \multirow{2}{*}{$\begin{array}{l}\text { Species } \\
\text { Totals }\end{array}$} \\
\hline & & 1 & 2 & 3 & 4 & 5 & 6 & 7 & 8 & 9 & \\
\hline \multirow[t]{4}{*}{ White sucker } & Jun, 2006 & 2 & 3 & 4 & 12 & 7 & 3 & 2 & 1 & 3 & 37 \\
\hline & Jul-Aug, 2006 & 2 & 3 & 1 & 1 & 7 & 4 & 0 & 0 & 3 & 21 \\
\hline & Oct-Nov, 2006 & 2 & 1 & 2 & 3 & 3 & 1 & 3 & 3 & 4 & 22 \\
\hline & Jul, 2007 & 0 & 5 & 0 & 9 & 7 & 2 & 2 & 2 & 0 & 27 \\
\hline \multirow[t]{3}{*}{ Other spp.§ } & Jun, 2006 & 0 & 0 & 1 & 0 & 0 & 0 & 0 & 0 & 0 & 1 \\
\hline & Jul-Aug, 2006 & 0 & 0 & 0 & 0 & 0 & 0 & 0 & 1 & 0 & 1 \\
\hline & Oct-Nov, 2006 & 0 & 0 & 1 & 1 & 0 & 0 & 0 & 0 & 1 & 3 \\
\hline
\end{tabular}

† Shiner species include common (Notropis cornutus), spotfin (Notropis spilopterus), and spottail (Notropis hudsonius) shiners.

¥ Sunfish species include bluegill (Lepomis macrochirus), green (Lepomis cyanellus), pumpkinseed (Lepomis gibbosus), and their hybrids.

$\S$ Other species include single occurrences of banded killifish (Fundulus diaphanus), black bullhead (Ictalurus melas), bluntnose minnow (Pimephales notatus), chinook salmon (Oncorhynchus tshawytscha), and yellow perch (Perca flavescens).

Nonmetric multidimensional scaling ordination of fish community composition in the Pigeon River required 40 iterations to produce a 2 dimensional solution with a final stress of 13.27 and instability of $<0.00001$, which is indicative of a stable solution (McCune and Grace 2002). The two ordination axes explained $91 \%$ of the variation between ordination distances and distances in the original dimensional space of the data (Figure 4). Axis 1 was positively correlated with central mudminnow $(r=0.84) \%$ abundance and negatively correlated with sunfish $(r=-0.61)$ and largemouth bass $(r=$ $-0.48) \%$ abundance. Axis 2 was positively correlated with sunfish $(r=0.75)$ and largemouth bass $(r=0.38) \%$ abundance, and negatively correlated with darter $(r=-0.85)$ and round goby $\%$ abundance $(r=-0.73)$. Tight clustering of ordination points among stations and sampling dates for Stations 1-6 (Figure 4a) indicates that fish community composition was fairly stable at Stations 1 to 6, with the exception of Station 3, which in the summer of 2007 was shifted toward greater \% abundance of central mudminnows and darters and lower \% abundance of sunfishes and largemouth bass (Table 5).

In contrast to the stations surveyed in the upper reaches of the Pigeon River, at Stations 7, 8 and 9, fish community compositions experienced obvious seasonal variations, showing substantial changes between early 


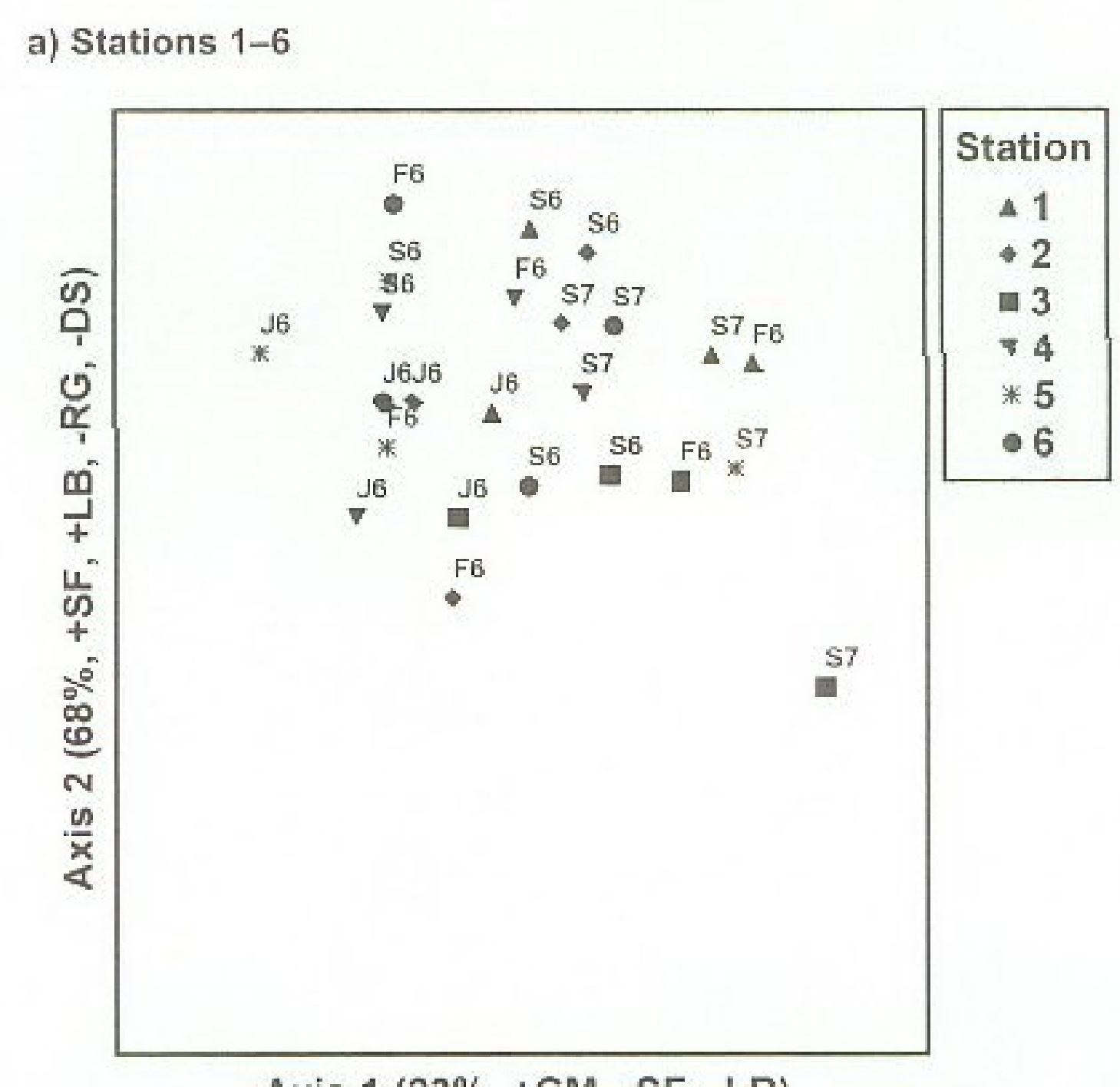

Axis $1(23 \%,+C M,-S F,-L B)$

b) Stations $7-9$

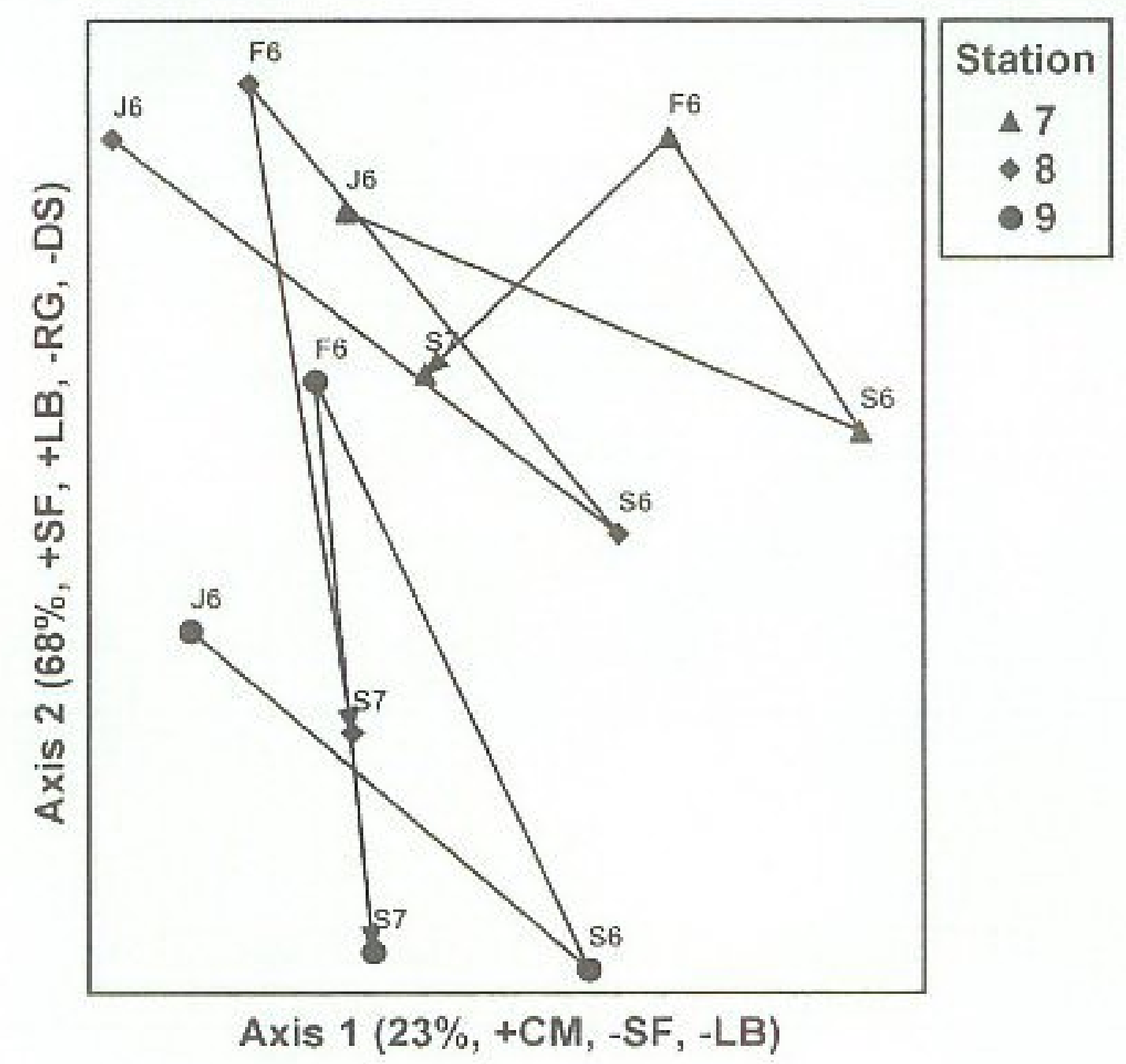

FIGURE 4. Nonmetric multidimensional scaling plots of fish community compositions from a) Stations 1-6 and b) Stations 7-9 in the Pigeon River, Ottawa County, Michigan, based on percentage composition by major species groups. Axes in both panels are shown at the same scale, with $\mathrm{r}^{2}$ values associated with each axis shown as \%. Pearson correlations between major species groups and ordination axes indicated as + or - for CM (central mudminnows), DS (darter species), LB (largemouth bass), RG (round gobies), and SF (sunfish species). Sampling dates indicated as J6 (June, 2006), S6 (Summer, 2006), F6 (Fall, 2006), and S7 (Summer, 2007). Directions of seasonal community composition changes shown in b) as linear vectors.

summer and fall to mid-summer in 2006 and 2007 (Figure 4b). This was especially pronounced for Stations 8 and 9 , where fish community compositions consistently shifted toward dominance by smaller fishes (darters, central mudminnow, and round goby) and away from larger native fishes (sunfishes and largemouth bass) during mid-summer in both 2006 and 
2007. This same pattern was present at Station 7 in 2006 but was less pronounced in 2007, perhaps a result of our having moved this station to a stretch where a single channel contained the main flow of the stream. The seasonal shift in species composition was strongly evident in both years at Station 9 (Figure $4 \mathrm{~b}$ ), however, even though the entire flow of the stream is contained in one channel throughout this fairly deep stretch (Table 4).

\section{Brown Trout Survival}

Beginning in 2003, approximately 2000 brown trout fingerlings ( 5 to 6 in) have been stocked in the Pigeon River each spring, with approximately equal numbers released near Stations 1, 6, and 9. Stocking records indicate that Gilchrist Creek-strain brown trout were stocked in 2003 and 2004, and Seeforellen-strain brown trout were stocked in 2005, 2006, and 2007 (MDNR 2010). We found brown trout of various sizes at all stations at some point during our fish surveys (Table 5). Brown trout were present in two distinct size classes in June and August of 2006, either 6 to 9 in or 15 to 18 in (Figure 5). During this time period, we found no brown trout 9 to 15 in, suggesting that one or more year classes of stocked trout were no longer present. Based on lengths and scale ageing (Mays 2007), the 6 to 9 in fish that we found in 2006 were predominantly from that year's planting of the Seeforellen strain. Scale ageing (Mays 2007) also confirmed that the 15 to 18 in trout that we found in 2006 were survivors from 2003 and 2004 plants of Gilchrist Creek-strain fish. The missing year class in 2006 appeared to be

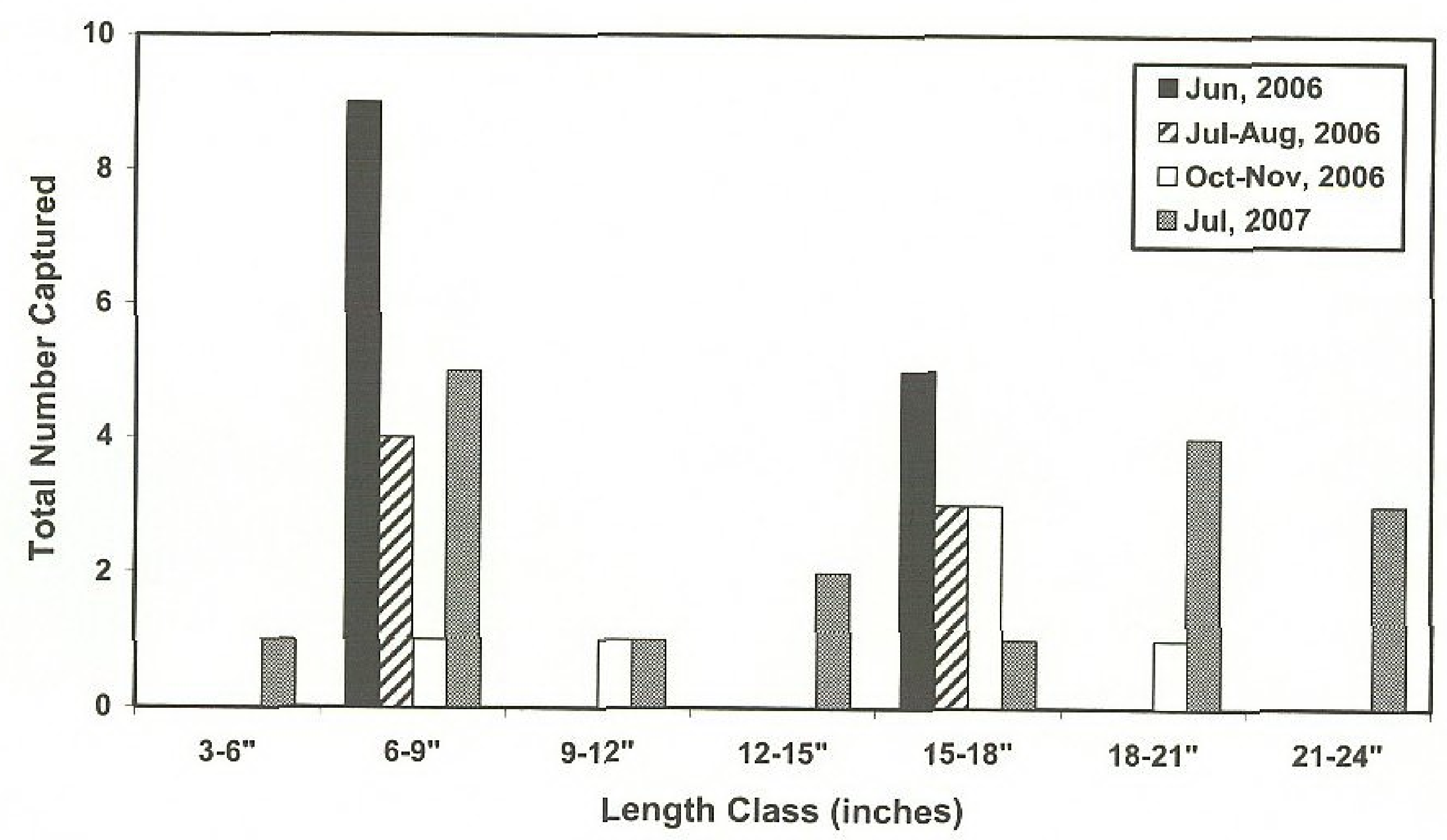

FIGURE 5. Distribution of brown trout by length class in the Pigeon River, Ottawa County, Michigan (2006-2007). 
the 2005 planting of Seeforellen-strain trout. In contrast, at least three year classes were present in 2007 (Figure 5), primarily consisting of smaller trout planted in 2006 and 2007, and larger trout surviving from 2003 and 2004 releases.

\section{DISCUSSION}

\section{Water Quality and Hydrology}

In addition to the effects of annual and seasonal variations in precipitation, hydrologic fluctuations in this system are exacerbated by the extensive drainage of wetlands and channelization of tributaries in the upper watershed. High stormflows from the upper watershed also are accompanied by episodes of degraded water quality, especially problematic if they occur during the summer (MacDonald et al. 2001). Past stream channelization and wetland drainage in the upper part of this watershed also contributes to low baseflow because water previously held and released slowly as phreatic or hyporheic groundwater (Poole and Berman 2001) is now rapidly translated downstream through the artificial drainage network. Because of fairly low summer baseflows in this system, large irrigation withdrawals during the summer greatly diminish daytime stream flows in the Pigeon River, creating increased hydrologic instability in the lower mainstream that may produce seasonal instability in the biotic community (Gorman and Karr 1978; Bain et al. 1988).

Most changes in water quality observed during this study were associated with improved wastewater treatment at the point source, but also would include changes in the magnitudes of nonpoint sources in the upper watershed resulting from implementation of best management practices through the watershed project. While inorganic $\mathrm{N}$ and $\mathrm{P}$ concentrations remained in the range typical of many agricultural watersheds (e.g., Omernik 1976; Beaulac and Reckhow 1982), $\mathrm{PO}_{4}-\mathrm{P}$ and $\mathrm{NO}_{3}-\mathrm{N}$ concentrations measured during recent years were less than those measured during the late 1990s (MacDonald et al. 2001), consistent with gradual improvements in water quality. Observed trends toward reduced $\mathrm{PO}_{4}-\mathrm{P}, \mathrm{NH}_{4}-\mathrm{N}, \mathrm{NO}_{3}-\mathrm{N}$, and suspended solids concentrations through time in the Pigeon River are similar to water quality improvements documented in Swedish streams that were subsequently recolonized by brown trout (Eklov et al. 1998). The cold transition thermal regime observed in the lower mainstream of the Pigeon River is considered optimal for brown trout (Wehrly et al. 2003; Lyons et al. 2009), and is consistent with the stream's current coldwater fishery management designation. Higher dissolved oxygen levels also are associated with improved conditions for brown trout (Eklov et al. 1998), suggesting that stations in the lower Pigeon River should be most suitable for this species if appropriate hydrologic stability and habitat are present (Naslund et 
al. 1998; Elliot 2000; Neumann and Wildman 2002). Since reinitiation of trout stocking in 2003, water quality in the Pigeon River has continued to show signs of gradual improvement, consistent with multi-year lag times observed after remediation in other watersheds (Meals et al. 2010).

Based on benthic macroinvertebrate surveys conducted by students at various locations in the Pigeon River between 2005 and 2008 following a volunteer stream monitoring protocol (MDEQ 2002a), stream quality scores consistently fell in the fair to good categories (N.W. MacDonald, unpublished data). Stream quality scores typically improved from "fair" at monitoring Stations II and III in the drains of the upper watershed to "good" at monitoring Stations V and VI in the lower mainstream, consistent with the results of water quality monitoring. The macroinvertebrate community in the mainstream of the Pigeon River commonly includes stoneflies (Taeniopterigidae), mayflies (Leptophlebiidae, Heptageniidae), caddisflies (Limnephilidae, Hydropsychidae, Phryganeidae, Polycentropodidae, Philopotamidae), amphipods (Gammaridae), isopods (Asellidae), black flies (Simuliidae), midges (Chironomidae), other Diptera (Athericidae, Culicidae, Tabanidae, Tipulidae), true bugs (Belostomatidae, Corixidae, Gerridae, Nepidae, Notonectidae, Veliidae), water beetles (Dytiscidae, Gyrinidae, Haliplidae, Hydrophilidae), dragon flies (Anisoptera), damsel flies (Coenagrionidae), hellgrammites (Corydalidae), alderflies (Sialidae), and crayfish (Decapoda). In addition to confirming the generally improving water quality in the mainstream of the Pigeon River, these macroinvertebrate populations also are an important part of the food web that supports the fish population in this sandy, low-gradient stream (e.g., Benke et al. 1985).

\section{Stream and Habitat Characteristics}

In general, habitat values and brown trout growth are better in areas of stream segments with deeper water (Greenberg and Dahl 1998; Lamouroux and Capra 2002), suggesting that Stations 2, 4, 5, 6, and 9 might provide more optimal physical habitat for this species. More importantly, most stretches contained substantial quantities of large woody debris and areas of logjams and brush deposits (Figure 3). These structures provide vital substrate for macroinvertebrates (Benke et al. 1985), shelter for many fish species, and can be especially important for survival of brown trout (Bunt et al. 1999; Harwood et al. 2002). Woody debris is an important component of trout habitat in addition to physical habitat dimensions related to stream width and depth (Neumann and Wildman 2002) and also is associated with cold water patches used by trout as summer refugia in marginal streams (Ebersole et al. 2003). The entire stretch of the Pigeon River that we studied is a county drain, and even though it is managed as a coldwater fishery by the MDNR, public demands to facilitate drainage in the upper parts of the 
watershed leave the mainstream of the Pigeon River subject to periodic proposals to remove large woody debris. Such projects would not only destroy essential macroinvertebrate and fish habitat, but also could contribute to reduced flows of hyporheic groundwater by reducing channel heterogeneity (Poole and Berman 2001). Preserving all types of woody debris as a natural channel characteristic in the lower mainstream of the Pigeon River is critical for preserving suitable habitat for trout and other fish species since it is one of the only permanent structural elements in this sand-based system (Wiley and Seelbach 1998). Similarly, the existing riparian floodplain forest is not only the source of woody debris and other organic matter inputs into this system, its shade provides thermal stability to help maintain the coolwater thermal regime, and thus is a key watershed element that should be protected in its intact state.

Because of the sandy nature of the streambed (Mays 2007), the absence of naturally occurring coarse substrates is a critical habitat limitation in this system (Huusko and Yrjana 1997; Maki-Petays et al. 1997; Harwood et al. 2002). The few gravel deposits suitable for spawning are heavily used by both trout and salmon in the spring and fall (e.g., above Station 9, N.W. MacDonald, personal observation). While no young-of-the-year trout or salmon were collected during fish surveys in either 2006 or 2007, angler reports of small rainbow trout (Oncorhynchus mykiss) occasionally being caught in the stream suggest that there may be sporadic natural reproduction of this species. Addition of gravel to select areas of the lower mainstream might facilitate successful spawning of either trout or salmon, but continued stocking with hatchery-reared fingerlings may be the only feasible way of maintaining a resident brown trout population in the Pigeon River given the relative lack of suitable spawning substrate.

\section{Fish Community Composition}

Of the fish species we observed in the Pigeon River, most represented typical coolwater or warmwater species found in many southern Michigan streams (Roth et al. 1996; Wehrly et al. 2003; Lyons et al. 2009). The fish community composition also was affected by the stream's open connection to Lake Michigan (Wiley and Seelbach 1998), including the seasonal occurrence of migratory rainbow trout and chinook salmon (Oncorhynchus tshawytscha) as well as the presence of invasive species such as the round goby (Table 5). Since round gobies were not observed in the Pigeon River in 2000 (N.W. MacDonald, unpublished data), it is likely that those we observed in the Pigeon River in 2006 and 2007 represented recent dispersal from source populations in Pigeon Lake or Lake Michigan (Cooper et al. 2007). The Pigeon River as a whole met its coldwater fishery designated use on all survey dates by having $1 \%$ or greater of its fish community represented 
by salmonids (Creal et al. 1998; MDEQ 2002b). Meeting this minimum management standard in no way suggests that the Pigeon River represents a healthy coldwater system dominated by trout and other pollution-intolerant species. Instead, as a coolwater stream, it offers an opportunity to establish and maintain a brown trout population because of its suitable thermal regime (Lyons et al. 2009).

The lower mainstream of the Pigeon River typically falls into the cold transition thermal category based on mean July temperatures (Zorn et al. 2008; Lyons et al. 2009). Most of the fish species found in the Pigeon River, however, are classified in the warm transition to warmwater categories (Lyons et al. 2009), suggesting that landscape-scale watershed degradation has caused the current fish assemblage to shift away from coolwater toward warmwater species composition. This is a typical response of coldwater systems to environmental degradation (Lyons et al. 1996), and is consistent with the heavily agricultural land use in the upper watershed of the Pigeon River (Wang et al. 2003). For example, Baker et al. (2005) found that agricultural land use was a significant predictor of the number of sunfish species found in streams in the upper Great Lakes region, consistent with the abundance of the three sunfish species (Table 5) we observed in the Pigeon River. The current fish assemblage in the Pigeon River is a manifestation of the historic agricultural land use in the upper watershed, being strongly shifted toward pollution-tolerant, eurythermal species (Lyons et al. 1996).

Extensive drainage of the upper watershed creates substantial hydrologic instability in the system, manifested both by low baseflows in the summer and high stormflows during snowmelt or after intense rainfall. Episodic summer storms, especially, are accompanied by flows of degraded water from the upper watershed, and high biochemical oxygen demand in these stormflows can reduce dissolved oxygen to levels stressful to pollutionintolerant fish species (Wiley and Seelbach 1998; MacDonald et al. 2001) even though maximum temperatures may not exceed the ranges typical for coolwater systems $\left(20.7-24.6^{\circ} \mathrm{C}\right)$. For example, unusually large summer stormflows in the lower mainstream of the Pigeon River in June and July of 1997 had temperatures ranging from 21.4 to $22.7^{\circ} \mathrm{C}$, but dissolved oxygen concentrations ranging from 2.5 to $4.4 \mathrm{mg} \mathrm{L}^{-1}$. The only remedy for this type of hydrologic instability coupled with degraded water quality involves additional efforts to implement agricultural best management practices and to restore or create wetland or similar stormwater retention systems throughout the upper watershed of this stream, as previously recommended by PRWAC (1997), Wiley and Seelbach (1998), and MacDonald et al. (2001).

The results of our fish surveys also revealed a seasonal change in fish community composition that occurred at the three stations downstream from 
a large irrigation withdrawal, but not at the six stations upstream from the irrigation withdrawal (Figure 4). The upper six stations all represent the main channel of the stream, have relatively good water quality (Table 2), are fairly deep (Table 4), have good amounts of large woody debris for cover (Figure 3), and do not experience extreme variation in baseflows during the summer (Figure $2 \mathrm{a}$ ). All of these factors would contribute to the relatively stable fish community composition that we observed at these six stations (Gorman and Karr 1978; Bain et al. 1988). In contrast to the stations surveyed in the upper reaches of the Pigeon River, at Stations 7, 8 and 9, fish community compositions experienced obvious seasonal variations, showing substantial changes between early summer and fall to mid-summer in 2006 and 2007 (Figure 4b). Since Stations 7, 8, and 9 are downstream from a large irrigation withdrawal, the resulting high variability in summer stream flow (Figure 2b) may be responsible for degraded habitat availability and seasonally altered fish community structure at these stations (Gorman and Karr 1978; Bain et al. 1988).

It is unlikely that poor water quality is implicated in this seasonal shift in fish community composition, because water quality is typically highest in the lower reaches of the Pigeon River throughout the year (Table 2; MacDonald et al. 2001). It is possible that midsummer stream temperatures at the lower three stations (Table 3), which are below preferred temperatures $\left(24-28^{\circ} \mathrm{C}\right)$ for sunfishes and largemouth bass, cause these species to migrate to find warmer water. If this were true, then we would expect to see a similar shift in species composition at the upper six stations that had similar summer water temperatures (Table 3), but fish community composition did not change dramatically at the upper stations in 2006 or 2007 (Table 5, Figure 4a). In contrast, up to half the flow of the Pigeon River is removed during active irrigation periods, far exceeding the level of withdrawal predicted to cause changes in fish assemblages in cold transition streams (Zorn et al. 2008). The extreme variation in daily flows caused by irrigation withdrawals in the lower reaches of the Pigeon River creates environmental stress (e.g., Baran et al. 1995; Heggenes et al. 1999), and it is likely that this variation in discharge also is implicated in the seasonal changes in fish community composition that we observed.

\section{Brown Trout Survival}

Length-frequency data for the Pigeon River show that $90 \%$ of its fish are less than 6 in long (Mays 2007). Abundant darters, central mudminnows, and sunfishes less than 3 in provide potential forage, and growth of brown trout has been shown to be positively related to the number of coexisting fish species (Naslund et al. 1998). Round gobies also are potential prey for piscivores (Ruetz et al. 2009), and the larger brown trout found in the Pigeon 
River may opportunistically feed on this species as well. The only resident species with lengths consistently greater than 6 in observed in the Pigeon River included white suckers, common carp, northern pike, and brown trout (Mays 2007). Northern pike are voracious predators (Hyvarinen and Vehanen 2004), and may be one source of mortality of stocked brown trout in the Pigeon River. The low numbers of brown trout found in the Pigeon River is consistent with their abundance being negatively associated with the number of coexisting fish species, and their survival being reduced as a result of both predation and competition for habitat (Naslund et al. 1998).

In both 2006 and 2007, we typically found smaller trout (6 to 9 in) close to stocking locations, consistent with hatchery fish initially tending to remain near their site of stocking (Jonsson et al. 1999; Sundstrom et al. 2004). In contrast, we found larger brown trout ( $>15$ in) wherever there were deep pools with large woody debris and slower-moving water, indicating subsequent dispersal of surviving trout throughout the stream to locations offering the best habitat (Maki-Petays et al. 1997; Naslund et al. 1998; Neumann and Wildman 2002). Deep pools with woody debris for cover are especially important for trout survival during summer droughts (Elliot 2000; Ebersole et al. 2003) and during periods of high flows (Bunt et al. 1999), both aspects of the hydrologic instability that typify the Pigeon River. The relatively low numbers of recently stocked fish captured in both 2006 and 2007 (Figure 5) is similar to reports by Aarestrup et al. (2005) of $74 \%$ of stocked brown trout either dying or emigrating within 5 weeks of introduction in a Danish stream. Both stocking records and scale ageing (Mays 2007) suggested that the smaller trout we captured represented the Seeforellen strain stocked between 2005 and 2007, while the larger fish we captured were from the initial 2003 and 2004 stocking of Gilchrist Creek-strain brown trout. While strain identities would need to be confirmed by genetic analyses (e.g., Tiano et al. 2007), the distribution by size and age is consistent with what has been observed about differential survival between these two strains of trout.

Gilchrist Creek-strain brown trout, derived from a naturally reproducing population in northern lower Michigan, survive well in many Michigan streams (Wills 2006). The Seeforellen strain, in contrast, has poorer survival in Michigan streams (Wills 2006), and tends to migrate downstream to reservoirs, lakes, or the sea (Humphreys et al. 2005). Downstream movement of recently stocked trout in the Pigeon River may occur with high spring discharge (e.g., Hembre et al. 2001; Aarestrup et al. 2002), but Weiss and Kummer (1999) concluded that strain-specific behaviors governed poststocking movements of brown trout more than stream discharge. If this is true in the Pigeon River, then many of the Seeforellen-strain trout stocked in 2005, 2006, and 2007 may have migrated downstream to Lake Michigan. In 2006, numerous 6 to 9 in brown trout were collected in the cool-water 
intake at the J.R. Campbell Generating Complex near the mouth of the Pigeon River soon after the Pigeon River was stocked (A. Parker, personal communication), consistent with rapid downstream migration of stocked Seeforellen-strain trout.

The apparent absence of any brown trout stocked in 2005 also may be related to extremely low flows in the Pigeon River resulting from an extended drought during the summer of 2005. Rainfall recorded at the Muskegon National Weather Service Station between April and August 2005 totaled $19.7 \mathrm{~cm}$ compared to the 30-year average of $36.9 \mathrm{~cm}$ (NCDC 2009). Discharge at Station 9 was only $357 \mathrm{~m}^{3} \mathrm{~h}^{-1}$ on $9 / 14 / 2005$, one of the lowest mid-September discharges in our 13 years of record for the Pigeon River. Periods of low flow are associated with physiological stress and constraints on habitat, both of which would be compounded by the large irrigation withdrawals in the lower mainstream of the Pigeon River (Baran et al. 1995; Heggenes et al. 1999). The brown trout that survived the 2005 drought appeared to be from the Gilchrist Creek strain, which may have been better able to compete for space in pools that provide seasonal refugia (Elliot 2000; Nordwall et al. 2001; Harwood et al. 2002). It is notable that in 2006 we found large ( $>15 \mathrm{in}$ ) brown trout only above Station 7, in stretches of the stream that had good habitat and were not affected by the irrigation withdrawals below Station 6. In 2007, we did find a few large (> 18 in) brown trout at Station 7 after we relocated it to better represent the main channel. These fish also were found in deeper pools that would be less sensitive to the large daily fluctuations in discharge downstream of the irrigation withdrawal than the smaller side channels we sampled in 2006. The presence of brown trout at Stations 7, 8, and 9 in the summer of 2007 (Table 5) suggested that they were able to persist in this stretch notwithstanding the high variation in summer discharge, but reductions in discharge may negatively impact carrying capacities of brown trout (Baran et al. 1995) in the lower Pigeon River where both water quality and thermal regime are otherwise very suitable for this species.

No creel census data exist for the Pigeon River with which to evaluate the success of the brown trout stocking effort in terms of creation of a fishery. Anecdotal reports suggest that local anglers are aware of and utilize this resource, especially as extensive areas of county park land border the upper and lower reaches of the coldwater management stretch of the Pigeon River. While fishery managers might need to consider whether continued stocking is warranted given the current hydrologic instability in the system, the value of brown trout stocking should be considered in a wider context as well. Mature brown trout now represent some of the largest resident piscivores in the Pigeon River, and their presence not only provides opportunities for anglers to fish for sizeable trout in a local stream, it also augments the trophic 
diversity of this coolwater system (Karr 1981; Lyons et al. 1996). The reestablishment of brown trout in the Pigeon River, in concert with improved water quality, symbolizes the attainment of one of the specific goals of the Pigeon River Watershed Project, and conservation agencies and nonprofit organizations use this as justification when applying for funds to implement further watershed-based projects. The documented presence of trout in the mainstream of the Pigeon River demonstrates the MDNR's renewed commitment to maintaining the coldwater fishery designated use of the Pigeon River, and provides a strong argument against implementation of traditional drain maintenance activities that would remove naturally occurring woody debris from the lower mainstream in an attempt to address drainage concerns in the upper watershed. Local anglers have recently helped develop stream habitat improvement projects in the lower mainstream of the Pigeon River, involving Trout Unlimited, the Ottawa County Parks and Recreation Commission, the Timberland Resource Conservation and Development Council, the US Fish and Wildlife Service, and the Grand Haven Community Foundation (Daining 2010). While the low-density brown trout population that now exists in the Pigeon River might represent less than a total fishery management success, its public visibility has inspired renewed efforts to implement the watershed protection and restoration practices that will be required to establish and maintain a truly viable trout fishery.

\section{SUMMARY AND MANAGEMENT IMPLICATIONS}

As a result of MDEQ regulatory action to control a point source discharge and community-based watershed management efforts to begin reducing nonpoint source pollution, water quality in the Pigeon River gradually improved between 1996 and 2008. Our long-term water quality monitoring efforts, conducted in support of the Pigeon River Watershed Project, document point source reductions and subsequent improvement in water quality in the mainstream of the Pigeon River. Monitoring also confirmed that summer thermal regimes (July mean $<19^{\circ} \mathrm{C}$ ) and dissolved oxygen concentrations $(>6 \mathrm{mg} / \mathrm{L}$ ) consistently remained in the range suitable for trout, directly leading to the decision by the MDNR to resume stocking of brown trout. Continuous discharge measurements show that problems related to hydrologic instability continue to affect this stream, however, and both episodic high stormflows and low discharge resulting from heavy irrigation withdrawals represent environmental stresses in the lower mainstream in mid-summer. Fish surveys, conducted in cooperation with the MDNR to evaluate the outcome of trout stocking, also reveal that the fish assemblage is relatively stable in the upper mainstream of the Pigeon River, consistent with the relatively stable baseflow, water quality, habitat, 
and summer thermal regime in this part of the system. In contrast, in the lower mainstream, the fish community composition exhibits substantial seasonal variation in concert with increased variability in summer discharge caused by large irrigation withdrawals.

Results of stream monitoring and fish surveys demonstrate that water quality, thermal regime, in-stream habitat, and the forage base of macroinvertebrates and small fishes are generally suitable to maintain a stocked brown trout population in the Pigeon River. Throughout the study reach, natural stream channel characteristics and abundant woody debris provide shelter for brown trout and other fishes, representing critical habitat that needs to be protected. Brown trout are present in all of the stream stretches surveyed but not at high abundance, suggesting a combination of low survival and/or high emigration. Gilchrist Creek-strain trout from the 2003 and 2004 stockings, however, had grown well and are among the larger game fish in the Pigeon River, providing justification for continued stocking with this strain of brown trout. While the fish community in the Pigeon River is typical of those found in moderately impacted agricultural watersheds, survival of stocked brown trout provides additional evidence of improved water quality resulting from past pollution control efforts. Our studies document the positive outcomes of concerted efforts to improve water quality and reestablish a stocked brown trout population in the Pigeon River, but also reveal the negative effects of continued hydrologic instability. For example, the relatively low survival of brown trout illustrates that traditional pollution control measures can improve water quality, but may not restore game fish populations to a similar extent if factors associated with hydrologic instability are limiting. Results of our studies reemphasize the need for continued watershed-scale efforts to improve water quality, protect in-stream habitat, reduce high stormflows, and ensure adequate summer baseflows to maintain a desirable fish community in the Pigeon River, protect its coldwater fishery designated use, and assure its future value as a public resource.

\section{ACKNOWLEDGMENTS}

Funding for this study was provided by a Research Grant-in-Aid from the GVSU Faculty Research and Development Center and through a graduate assistantship provided by the GVSU Biology MS Program. The Annis Water Resources Institute, GVSU, provided laboratory support for water quality analyses. The Ottawa County Parks and Recreation Commission and several private landowners gave permission to access the Pigeon River at locations on their properties. The Ottawa Conservation District provided the recording thermometers used during 2006 in this study. Mark Luttenton, GVSU, and Amy Harrington, Regional Fisheries Biologist (retired), MDNR, 
provided invaluable advice and logistical support throughout the development and conduct of this research. Students in NRM 452, Watershed and Wetland Management, assisted with macroinvertebrate surveys, water sample collections, and sample analyses for the annual fall water quality monitoring study. Daniel Gloeden assisted with macroinvertebrate identifications in NRM 452 and conducted an independent macroinvertebrate survey in the Pigeon River as his senior capstone project in 2007. Two anonymous reviewers provided insightful and helpful comments, and the final version of the manuscript was substantially improved as a result. We thank all of these individuals for their unstinting assistance.

\section{LITERATURE CITED}

Aarestrup, K., C. Nielsen, and A. Koed. 2002. Net ground speed of downstream migrating radio-tagged Atlantic salmon (Salmo salar L.) and brown trout (Salmo trutta L.) smolts in relation to environmental factors. Hydrobiologia 483:95-102.

Aarestrup, K., N. Jepsen, A. Koed, and S. Pedersen. 2005. Movement and mortality of stocked brown trout in a stream. Journal of Fish Biology 66:721-728.

Anonymous. 1919. Mammoth drain will empty into lake at Sheldon. Grand Haven Daily Tribune, page 1, August 8.

APHA. 1992. Standard methods for the examination of water and wastewater. $18^{\text {th }}$ ed. American Public Health Association, Washington, DC.

Bain, M. B., J. T. Finn, And H. E. Booke. 1988. Streamflow regulation and fish community structure. Ecology 69:382-392.

Baker, E. A., K. E. Wehrly, P. W. Seelbach, L. Wang, M. J. Wiley, and T. SimON. 2005. A multimetric assessment of stream condition in the northern lakes and forests ecoregion using spatially explicit statistical modeling and regional normalization. Transactions of the American Fisheries Society 134:697-710.

Baran, P., M. Delacoste, F. Dauba, J.-M. Lascaux, A. Belaud, and S. LEK. 1995. Effects of reduced flow on brown trout (Salmo trutta L.) populations downstream dams in French Pyrenees. Regulated Rivers: Research and Management 10:347-361.

Beaulac, M. N., and K. H. RecKhow. 1982. An examination of land usenutrient export relationships. Water Resources Bulletin 18:1013-1024.

Benke, A. C., R. L. Henry, D. M. Gillespie, and R. J. Hunter. 1985. Importance of snag habitat for animal production in southeastern streams. Fisheries 10 (5): 8-13.

Bunt, C. M., S. J. Cooke, C. Katopodis, and R. S. McKinley. 1999. Movements and summer habitat of brown trout (Salmo trutta) below 
a pulsed discharge hydroelectric generating station. Regulated Rivers: Research and Management 15:395-403.

Cooper, M. J., C. R. Ruetz III, D. G. Uzarski, and T. M. Burton. 2007.

Distribution of round gobies in coastal areas of Lake Michigan: Are wetlands resistant to invasion? Journal of Great Lakes Research 33: 303-313.

Creal, W., and J. Wuycheck. 1998. Michigan Clean Water Act Section 303(d) List, submitted for 1998, revised 5/98. Michigan Department of Environmental Quality, Surface Water Quality Division, Lansing, Michigan.

Creal, W., S. Hanshue, S. Kosek, M. Oemke, and M. Walterhouse. 1998. "GLEAS Procedure 51 Metric Scoring and Interpretation." Chapter 25B in Schneider, James C. (ed.) 2000. Manual of fisheries survey methods II: With periodic updates. Michigan Department of Natural Resources, Fisheries Special Report 25, Ann Arbor.

Daining, P. 2010. Reclaiming Pigeon River: Trout groups work to upgrade river. Holland Sentinel, page A-3, September 5.

Ebersole, J. L., W. J. Liss, and C. A. Frissell. 2003. Thermal heterogeneity, stream channel morphology, and salmonid abundance in northeastern Oregon streams. Canadian Journal of Fisheries and Aquatic Sciences 60:1266-1280.

Eklov, A. G., L. A. Greenberg, C. Bronmark, P. Larsson, and O. BERGLUND. 1998. Response of stream fish to improved water quality: A comparison between the 1960s and 1990s. Freshwater Biology 40: $771-782$.

Elliott, J. M. 2000. Pools as refugia for brown trout during two summer droughts: trout responses to thermal and oxygen stress. Journal of Fish Biology 56:938-948.

Gorman, O. T., And J. R. KarR. 1978. Habitat structure and stream fish communities. Ecology 59:507-515.

Greenberg, L. A., AND J. DAhl. 1998. Effect of habitat type on growth and diet of brown trout, Salmo trutta L., in stream enclosures. Fisheries Management and Ecology 5:331-348.

Harwood, A. J., N. B. Metcalfe, J. D. Armstrong, and S. W. Griffiths. 2002. Intra- and inter-specific competition for winter concealment in juvenile salmonids. Canadian Journal of Fisheries and Aquatic Sciences 59:1515-1523.

Heggenes, J., J. L. Bagliniere, and R. A. Cunjak. 1999. Spatial niche variability for young Atlantic salmon (Salmo salar) and brown trout (S. trutta) in heterogenous streams. Ecology of Freshwater Fish 8:1-21. 
Hembre, B., J. V. Arnekleiv, and J. H. L'Abee-Lund. 2001. Effects of water discharge and temperature on the seaward migration of anadromous brown trout, Salmo trutta, smolts. Ecology of Freshwater Fish 10:61-64.

Humphreys, M., E. Machowski, N. T. Hagstrom, and E. Schluntz. 2005. State of Connecticut Federal Aid to Sport Fish Restoration F-57-R23 Segment Completion Report, April 1, 2000 to March 31, 2005, $73 \mathrm{pp}$.

HuUsKo, A., And T. YrJana. 1997. Effects of instream enhancement structures on brown trout, Salmo trutta L., habitat availability in a channelized boreal river: A PHABSIM approach. Fisheries Management and Ecology 4:453-466.

Hyvarinen, P., and T. Vehanen. 2004. Effect of brown trout size on poststocking survival and pike predation. Ecology of Freshwater Fish 13: 77-84.

Jonsson, S., E. Brannas, and H. Lundevist. 1999. Stocking of brown trout Salmo trutta L.: Effects of acclimatization. Fisheries Management and Ecology 6:459-473.

KarR, J. R. 1981. Assessment of biotic integrity using fish communities. Fisheries 6:21-27.

Karr, J. R., L. A. Toth, and D. R. Dudley. 1985. Fish communities in Midwestern rivers: A history of degradation. BioScience 35:90-95.

Lamouroux, N., and H. Capra. 2002. Simple predictions of instream habitat model outputs for target fish populations. Freshwater Biology 47:1543-1556.

Lyons, J., L. WANG, and T. D. Simonson. 1996. Development and validation of an index of biotic integrity for coldwater streams in Wisconsin. North American Journal of Fisheries Management 16:241256.

Lyons, J., T. Zorn, J. Stewart, P. Seelbach, K. Wehrly, and L. Wang. 2009. Defining and characterizing coolwater streams and their fish assemblages in Michigan and Wisconsin, USA. North American Journal of Fisheries Management 29:1130-1151.

MacDonald, N. W., R. R. Rediske, and J. E. Van Denend. 2001. Hydrologic events and water quality in the Pigeon River, Ottawa County, Michigan. Michigan Academician 32:155-173.

Maki-Petays, A., T. Muotka, A. Huusko, P. Tikkanen, and P. Kreivi. 1997. Seasonal changes in habitat use and preference by juvenile brown trout, Salmo trutta, in a northern boreal river. Canadian Journal of Fisheries and Aquatic Sciences 54:520-530. 
Mays, D. W. 2007. "Survival of brown trout (Salmo trutta) in the Pigeon River, Ottawa County, Michigan." M.S. thesis, Grand Valley State University, Allendale, Michigan.

McCune, B., And J. B. Grace. 2002. Analysis of ecological communities, MjM Software Design, Gleneden Beach, Oregon.

McCune, B., And M. J. MefFord. 2006. PC-ORD. Multivariate analysis of ecological data. Version 5. MjM Software Design, Gleneden Beach, Oregon.

MDEQ. 2002a. Volunteer monitoring of Michigan's rivers and streams, 1998-2001 report. MI/DEQ/SWQ-02/101, Michigan Department of Environmental Quality, Surface Water Quality Division, Surface Water Assessment Section.

MDEQ. 2002b. Qualitative biological and habitat survey protocols for wadable streams and rivers. Procedure $\# 51$, Michigan Department of Environmental Quality, Surface Water Quality Division, Great Lakes and Environmental Assessment Section.

MDNR. 2010. Fish stocking records for the Pigeon River, Ottawa County, Michigan. Michigan Department of Natural Resources. http://www. michigandnr.com/FISHTOCK/

Meals, D. W., S. A. Dressing, and T. E. Davenport. 2010. Lag time in water quality response to best management practices: A review. Journal of Environmental Quality 39:85--96.

Naslund, I., E. Degerman, and F. Nordwall. 1998. Brown trout (Salmo trutta) habitat use and life history in Swedish streams: Possible effects of biotic interactions. Canadian Journal of Fisheries and Aquatic Sciences 55:1034-1042.

NCDC. 2007. Record of river and climatological observation forms for the Holland Fire Department, Holland, Michigan, August and October, 2007. Data obtained from the National Climatic Data Center, Asheville, North Carolina. http://www.ncdc.noaa.gov/

NCDC. 2009. Local climatological data, annual summary with comparative data for Muskegon, Michigan (KMKG). Monthly precipitation data for 1980-2009 obtained from the National Climatic Data Center, Asheville, North Carolina. http://www.ncdc.noaa.gov/

Neumann, R. M., and T. L. Wildman. 2002. Relationships between trout habitat use and woody debris in two southern New England streams. Ecology of Freshwater Fish 11:240-250.

Nordwall, F., I. Naslund, and E. Degerman. 2001. Intercohort competition effects on survival, movement, and growth of brown trout (Salmo trutta) in Swedish streams. Canadian Journal of Fisheries and Aquatic Sciences 58:2298-2308. 
Omernik, J. M. 1976. The influence of land use on stream nutrient levels. EPA-600/3-76-014, Corvallis Environmental Research Laboratory, USEPA, Corvallis, Oregon.

Poff, N. L., ANd J. D. Allan. 1995. Functional organization of stream fish assemblages in relation to hydrological variability. Ecology 76:606627.

Poole, G. C., And C. H. Berman. 2001. An ecological perspective on instream temperature: Natural heat dynamics and mechanisms of human-caused thermal degradation. Environmental Management 27: 787-802.

PRWAC (Pigeon River Watershed Advisory Committee). 1997. Comprehensive non-point source watershed management plan, Ottawa County, MI. Timberland RC\&D and Ottawa Soil and Water Conservation District, Grand Haven, Michigan.

Roth, N. E., J. D. Allan, and D. L. Erickson. 1996. Landscape influences on stream biotic integrity assessed at multiple spatial scales. Landscape Ecology 11:141-156.

Ruetz III, C. R., D. L. Strouse, and S. A. Pothoven. 2009. Energy density of introduced round goby compared with four native fishes in a Lake Michigan tributary. Transactions of the American Fisheries Society 138:938-947.

Steel, R. G. D., and J. H. Torrie. 1980. Principles and procedures of statistics: A biometrical approach. $2^{\text {nd }}$ ed. McGraw-Hill, New York.

Sundstrom, L. F., T. Bohlin, And J. I. Johnsson. 2004. Densitydependent growth in hatchery-reared brown trout released into a natural stream. Journal of Fish Biology 65:1385-1391.

Tiano, T. J., C. M. Willis, A. A. Noble, M. R. Luttenton, and A. G. Nikitin. 2007. Genetic identification of hatchery stocks of brown trout (Salmo trutta) using mitochondrial DNA polymorphism. North American Journal of Fisheries Management 27:965-970.

Wang, L., J. Lyons, P. Rasmussen, P. Seelbach, T. Simon, M. Wiley, P. Kanehl, E. Baker, S. Niemela, and P. M. Stewart. 2003. Watershed, reach, and riparian influences on stream fish assemblages in the Northern Lakes and Forest Ecoregion, U.S.A. Canadian Journal of Fisheries and Aquatic Sciences 60:491-505.

Wehrly, K. E., M. J. Wiley, and P. W. Seelbach. 2003. Classifying regional variation in thermal regime based on stream fish community patterns. Transactions of the American Fisheries Society 132:18-32.

Weiss, S., And H. Kummer. 1999. Movement of wild and experimentally stocked brown trout, Salmo trutta L., before and after a flood in a small Austrian stream. Fisheries Management and Ecology 6:35-45. 
Wiley, M. J., And P. W. Seelbach. 1998. An ecological assessment of opportunities for fishery rehabilitation in the Pigeon River, Ottawa Co. Report to the Pigeon River Watershed Advisory Committee, Ottawa Soil and Water Conservation District, Grand Haven, Michigan.

WILKINSON, L. 1989. SYSTAT: The system for statistics, Version 4. Evanston, IL, SYSTAT, Inc.

WiLLS, T. C. 2006. Comparative abundance, survival, and growth of one wild and two domestic brown trout strains stocked in Michigan rivers. North American Journal of Fisheries Management 26:535-544.

Wills, T. C., T. G. Zorn, And A. J. Nuhfer. 2006. "Stream Status and Trends Program sampling protocols." Chapter 26 in, Schneider, James C. (ed.). 2000. Manual of fisheries survey methods II: With periodic updates. Michigan Department of Natural Resources, Fisheries Special Report 25, Ann Arbor.

Zorn, T. G., P. W. Seelbach, E. S. Rutherford, T. C. Wills, S.-T. Cheng, And M. J. Wiley. 2008. A regional-scale habitat suitability model to assess the effects of flow reduction on fish assemblages in Michigan streams. Michigan Department of Natural Resources, Fisheries Research Report 2089, Ann Arbor. 